\title{
Review on Heat Transfer Enhancement by Louvered Fin
}

\author{
Samsul Islam, Md. Shariful Islam and Mohammad Zoynal Abedin
}

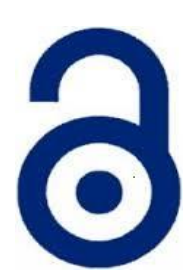

Received: 15 October 2020

Accepted: 28 January 2021

Published: 30 January 2021

Publisher: Deer Hill Publications

(c) 2021 The Author(s)

Creative Commons: CC BY 4.0

\begin{abstract}
The heat transfer enhancement is recycled in many engineering uses such as heat exchangers, refrigeration and air conditioning structures, chemical apparatuses, and automobile radiators. Hence many enhancing extended fin patterns are developed and used. In multi louvered fin, in this segment for multi-row fin and tube heat exchanger, an increase in heat transfer enhancement is found $58 \%$ for $\mathrm{Re}_{\mathrm{H}}=350$. When the Reynolds number is 1075 , the temperature gradient is more distinct for greater louver angle that is the higher heat transfer enhanced for large louver angle. For variable louver angle heat exchanger, the maximum heat transfer improvement achieved by $118 \%$ Reynolds number at 1075. In the vortex generator for the delta winglet vortex generator, the extreme enhancement of heat transfer increased to $16 \%$ compared to the baseline geometry (at $\operatorname{Re}_{\mathrm{Dh}}=600$ ). For a compact louvered heat exchanger, the results showed that a regular arrangement of louvered fins gives a $9.3 \%$ heat transfer improvement. In multi-region louver fins and flat tubes heat exchanger, the louver fin with 4 regions and the louver fin with 6 regions are far better than the conventional fin in overall performance. At the same time, the louver fin with 6 regions is also better than the louver fin with 4-region. The available work is in experimental form as well as numerical form performed by computational fluid dynamics.
\end{abstract}

Keywords: Heat Transfer enhancement, Louvered fin heat exchanger, Vortex generator, Compact heat exchanger, Multi-region louver fin.

NOMENCLATURE:

\begin{tabular}{ll}
\hline Abbreviation/Symbol & Meaning \\
\hline LP & Louver Pitch \\
$\mathrm{L}$ & Louver Length \\
$\theta$ & Louver Angle \\
$\mathrm{Re}$ & Reynolds Number \\
$\mathrm{Nu}$ & Nusselt number \\
$\mathrm{t}$ & Fin thickness \\
$\mathrm{H}$ & Fin pitch \\
$\mathrm{NI}$ & Number of Louvers \\
MRFTHE & Multi row fin and tube heat exchanger \\
DWVG & Delta winglet vortex generator \\
ILFHE & Inclined louvered fin heat exchanger \\
VLAHE & Variable louver angle heat exchanger \\
CLHE & Compact louvered heat exchanger \\
\hline
\end{tabular}

\section{INTRODUCTION}

Nowadays, Researchers are concentrating on the improvement of the performance of heat exchangers having a high degree of surface compactness and optimal overall thermal-hydraulic performance. In gas to a fluid heat exchanger, the thermal resistance is dominant on the gas side which is up to $80 \%$ to that of total thermal resistance in a heat exchanger. Therefore, the main reason for lower thermal performance on the gas side is attributed to the fact that approximately 10 to 50 times smaller heat transfer coefficient can be achieved for gas than that of fluid. Hence, it is widely expected to enhance the researches in the field of heat transfer enhancement for future applications in the

Samsul Islam, Md. Shariful Islam and Mohammad Zoynal Abedin 区

Department of Mechanical Engineering

Dhaka University of Engineering and Technology

Gazipur 1700, Bangladesh

E-mail: abedin.mzoynal@duet.ac.bd

Reference: Islam et al., (2021). Review on Heat Transfer Enhancement by Louvered Fin. International Journal of Engineering Materials and Manufacture, 60-80. 
engineering fields. It is widely used in air conditioning systems, power generation, automobiles, and other applications. An air-cooled heat exchanger is much more essential nowadays. When hot fluid flows inside the tubes and airflow outside the tubes acts as a cold fluid. Fins are usually used on the airside of air-cooled heat exchangers to increase heat transfer performance [1].

Louvered fins are widely used for air side heat transfer surface of heat exchangers, such as automotive radiators, air cooled oil coolers, intercoolers, heaters and the like. Heat transfer performance of louvered fins is largely affected by various and complicated flows changed by configuration and arrangement (length, angle, pitch). Although many researchers have reviewed various experimental studies for louver-fin heat exchanger, the papers reviewed heat transfer enhancement for the single louvered fin, multi louvered fin, relatively high louver angle, low fin pitch and compact heat exchanger. The following section deals with the enhancement techniques with a detailed analysis.

\section{ENHANCEMENT TECHNIQUES}

It can be divided into two groups. One is the "Active Technique" which requires an exterior power source to enhance heat transfer. The other one is the "Passive Technique" which requires no direct application of external power. The passive technique is an economical and widely used heat transfer enhancement technique. The heat transfer rate in heat exchanger is given by equation as,

$\mathrm{Q}=\mathrm{h} A \theta \mathrm{m}$

Where $\mathrm{h}$ is heat transfer coefficient, $\mathrm{A}$ is effective heat transfer surface area and $\theta \mathrm{m}$ is the mean value of temperature difference. The use of the passive technique to enhance heat transfer with considering the heat transfer equation is in the following manners.

1) Increase the effective heat transfer surface area A per unit volume without appreciably changing heat transfer coefficient h e.g. uses of plain fin surface.

2) Increase coefficient $h$ without changing area $A$ by using special shapes like crimped or ridged fins. That fin provides involvement due to subordinate flows and borderline coat parting within the channel.

3) Increase both $\mathrm{h}$ and $\mathrm{A}$ e.g. interrupting fins like louvers.

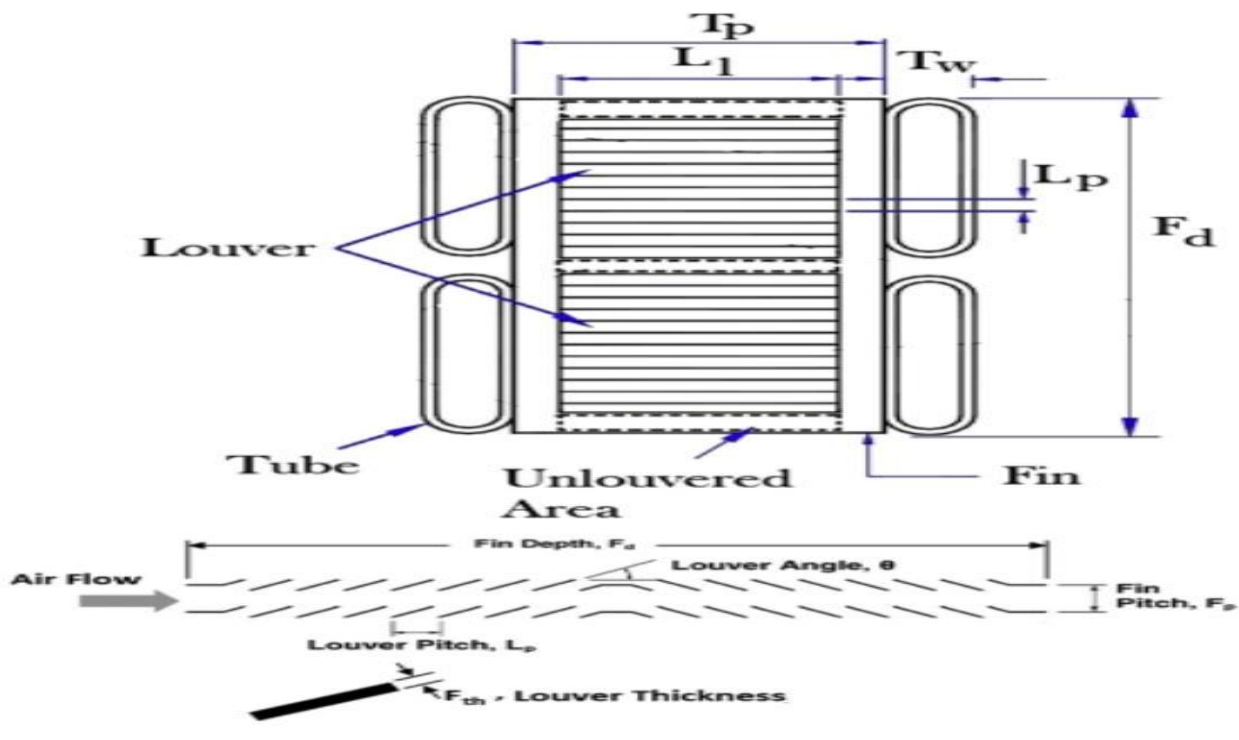

Figure 1: Typical louver fin pattern [2].

Louver fin pattern is one of the most advanced enhanced extended surfaces which are essentially formed by cutting the sheet metal of the fin at breaks and rotating the strips of a metallic object so formed out of the fin. Figure 1 shows the geometrical definition of a heat exchanger with louver fins. Louver fin has geometrical parameters like louver pitch, louver height, louver depth, louver angle, number of louvers, number of louver regions. Enhancement of heat transfer is dependent on geometrical parameters of louver fins hereafter researches are going on optimizing the thermo-hydraulic performance of heat exchanger with respect of louver type's enhancer. In this paper, it has been discussed on heat transfer enhancement by different types of louvered fin and also gives a comparison of heat transfer enhancement of various enhancement types. 


\section{SINGLE LOUVERED FINS}

\subsection{Single and double row tubes with louvered fins}

In this study, simulations are performed for Reynolds numbers (Red), ranging from 400 to 4000 . This is accomplished with the Reynolds number range established on louver pitch $\left(\operatorname{Re}_{\mathrm{LP}}\right)$ of 60 to 1800. As outlined in experimental observations of Antoniou et al., [3] have presented that the flow is laminar for up to a Reynolds number of nearly 1300. Although flow unevenness occurs upstream and downstream of the louver for $\operatorname{Re}_{\mathrm{Lp}}=1300$, the flow remains principally laminar. To discourse this issue, three-dimensional models are achieved in the existing study with the RNG $\mathrm{k}-\varepsilon$ turbulence model to estimate the heat transfer and pressure drop appearances and to verify the local turbulence behaviour of the flow field. The heat transfer results are found to be 6-7\% higher than those without the turbulence model. Since this difference is not so large, the assumption of laminar flow is retained for $\operatorname{Re}_{\mathrm{Lp}}$ up to 1300 . For $\operatorname{Re}_{\mathrm{Lp}}$ $>1300$, the turbulent flow equations are resolved. This study has implemented an arithmetical simulation of single and double row tubes with louvered fins. Figure 2 shows the computational domain used in the numerical study.
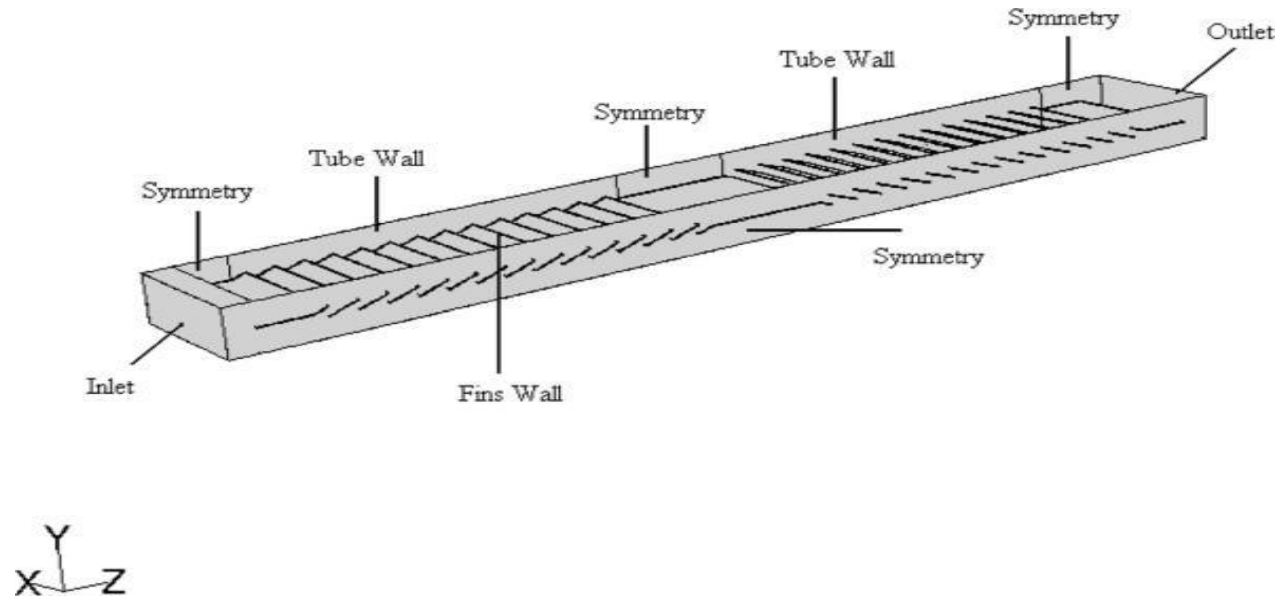

Figure 2: Computational domain louver fins [4].

It has been found that at a low Reynolds number maximum of air flows through the gap between the fins rather than through the louvers. Reynolds numbers, when it is higher the boundary layers everywhere the louvers are thinner and the flow is nearly united with the louvers. Here heat transfer rate is upgraded with Reynolds number. Heat transmission and pressure drop features are obtained in terms of non-dimensional parameters, Stanton number $(\mathrm{St})$, and friction factor (f) as functions of Reynolds number. There is a close contract is found between the computational results and experimental data at mid and high Reynolds numbers. Nonetheless, when Reynolds number is low then there is huge deviance. The local Nusselt number on the top surface of each louver in the flow direction along the length of fin for Reynolds number Red = 1000 is obtained; high Nusselt number is gained at the tip of the fin, leading-edge and rambling edge of every louver. It has observed that heat transfer coefficient increases with louver angle and extents maximum value at $(28-29)^{\circ}$ and then again falls with the rises in louver angle for fin pitch $2.17 \mathrm{~mm}$ also higher heat transmission coefficient is found at minor louver pitch, as $\mathrm{Lp}=0.81 \mathrm{~mm}$ at optimal louver angle. By decreasing the fin pitch from $3.33 \mathrm{~mm}$ to $2.11 \mathrm{~mm}$, the heat transfer rate increases. Although an additional decrease in louvered fin pitch does not result in any additional development in heat transfer.

\subsection{Louvered fin and tube heat exchanger}

Here the physical model and computational domain of the replicated louvered fin and tube heat exchanger are demonstrated in Figure 3 simple constraints of this geometry for two cases of validation and sensitivity study are demonstrated in Table 1.

For specifying the effect of Reynolds number on parameters $\mathrm{j} / \mathrm{j} 0$ and $\mathrm{f} / \mathrm{fO}$, these parameters vs. louver angles are shown in Figure 4. The velocity of air inlet was improved from $1 \mathrm{~m} / \mathrm{s}$ to $6.5 \mathrm{~m} / \mathrm{s}$ which produced in deviation of Reynolds number from 1250 to 8100 . It is demonstrated that maximum percentage changes of parameter $\mathrm{j} / \mathrm{j} 0$ is approximately $10 \%$, so the effect of Reynolds number on parameter $\mathrm{j} / \mathrm{j} 0$ can be ignored. This value is $16 \%$ for consideration $\mathrm{f} / \mathrm{fO}$ and it can also be unnoticed. 


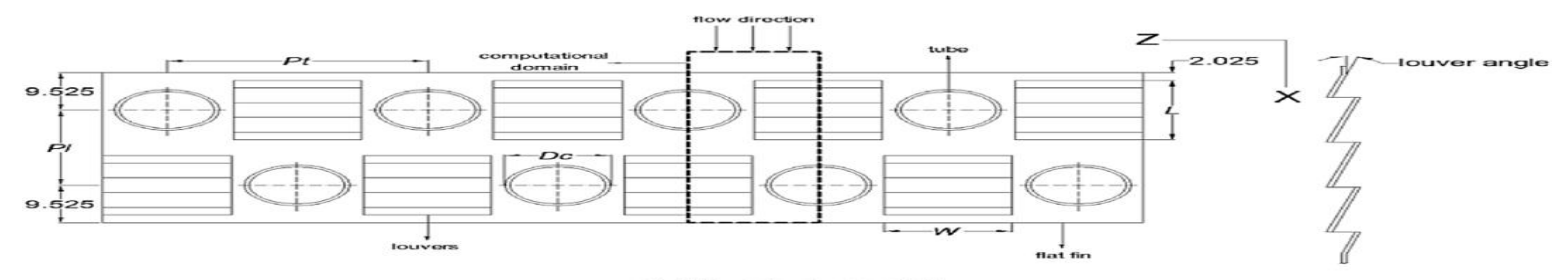

a) Physical model

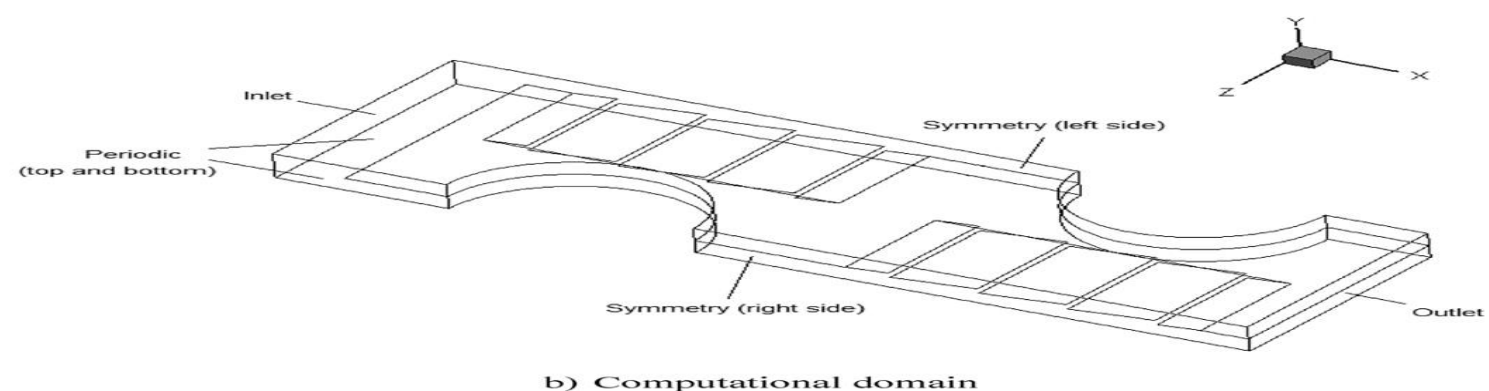

Figure 3: Physical model and computational domain [5].

Table 1: General Geometric Parameters of Simulated Louvered Fin [5].

\begin{tabular}{|l|c|c|c|}
\hline \multicolumn{1}{|c|}{ parameters } & $\begin{array}{c}\text { General values for } \\
\text { validation (flat fin) }\end{array}$ & $\begin{array}{c}\text { General values for } \\
\text { validation (louvered fin) }\end{array}$ & $\begin{array}{c}\text { General values for } \\
\text { parametric study }\end{array}$ \\
\hline Tube collar outside diameter (Dc) & $10.23 \mathrm{~mm}$ & $10.42 \mathrm{~mm}$ & $10.42 \mathrm{~mm}$ \\
\hline Tube row number & 2 & 2 & 2 \\
\hline Fin thickness (t) & $0.13 \mathrm{~mm}$ & $0.115 \mathrm{~mm}$ & $15 \mathrm{~mm}$ \\
\hline Length of louvered region (L) & - & $15 \mathrm{~mm}$ & 4 \\
\hline Number of louvers & - & 4 & $12.7 \mathrm{~mm}$ \\
\hline Width of louvered region (W) & - & $12.5 \mathrm{~mm}$ & $3.75 \mathrm{~mm}$ \\
\hline Fin pitch (Fp) & $2.24 \mathrm{~mm}$ & $2.06 \mathrm{~mm}$ & $19.05 \mathrm{~mm}$ \\
\hline Longitudinal tube pitch (pl) & $22 \mathrm{~mm}$ & $19.05 \mathrm{~mm}$ & $25.4 \mathrm{~mm}$ \\
\hline Transversal tube pitch (Pt) & $25.4 \mathrm{~mm}$ & $25.4 \mathrm{~mm}$ & $0-60^{\circ}$ \\
\hline Louver angle $(\theta)$ & - & $13.5^{\circ} \mathrm{mm}$ & \\
\hline
\end{tabular}

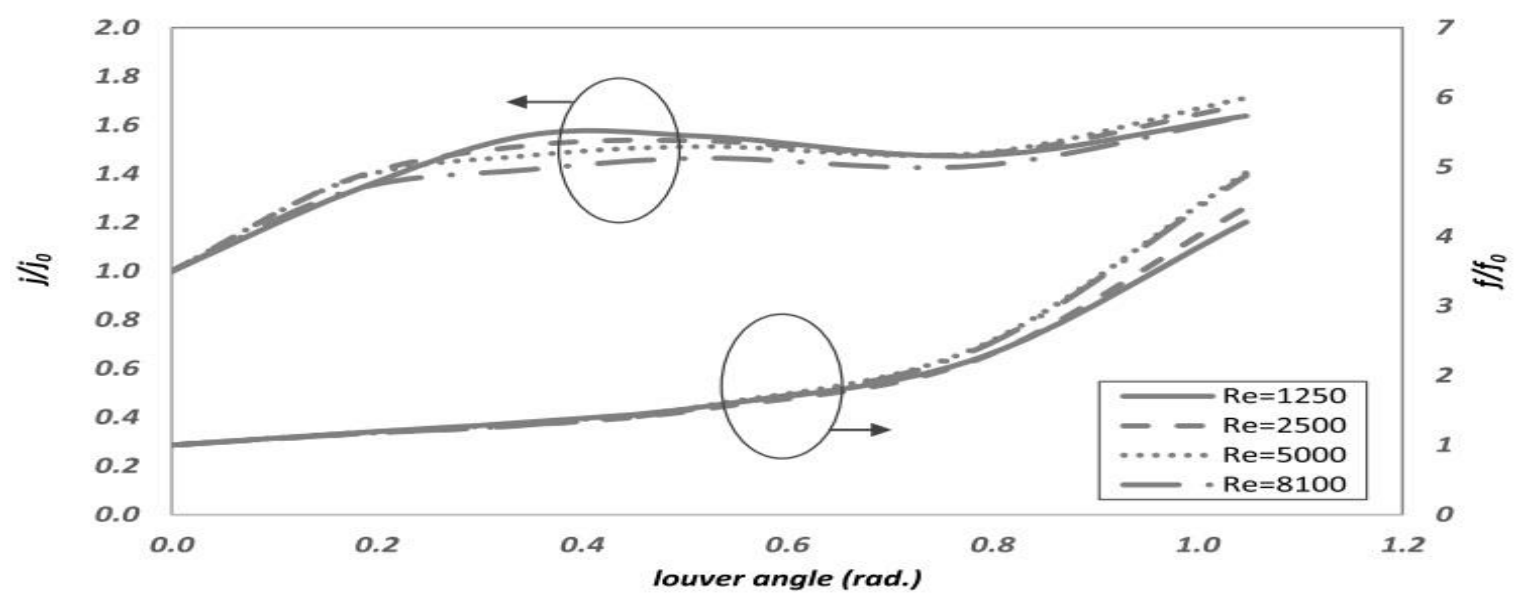

Figure 4: Effect of Reynolds number on parameters $\mathrm{j} / \mathrm{jO}$ and $\mathrm{f} / \mathrm{fO}$ in different louver angles [5]. 


\section{MULTI LOUVERED FINS}

4.1 Multi row fin and tube heat exchanger

The episodic geometry besides the tube and the symmetry alongside the airflow way has permitted for oversimplification of the model geometry. The geometric parameters of louvered fins are demonstrated in figure 5 . The hastened line in Figure 5 indicates the computational domain. A 3D design of the unit cell used in the condition of louvered fins is shown on Figure 6. Figure 6 shows the louvered fins solid body in impervious while the shaded volume indicates the fluid zone. The CAD tool used allows for simplicity in adjusting the variable design parameters $(\mathrm{L}, \mathrm{Lp}, \mathrm{NI}, \theta)$. The values for the main design constraints are recorded in Table 2 with the inconstant factors, as analysed in this paper, and are shown as ranges.

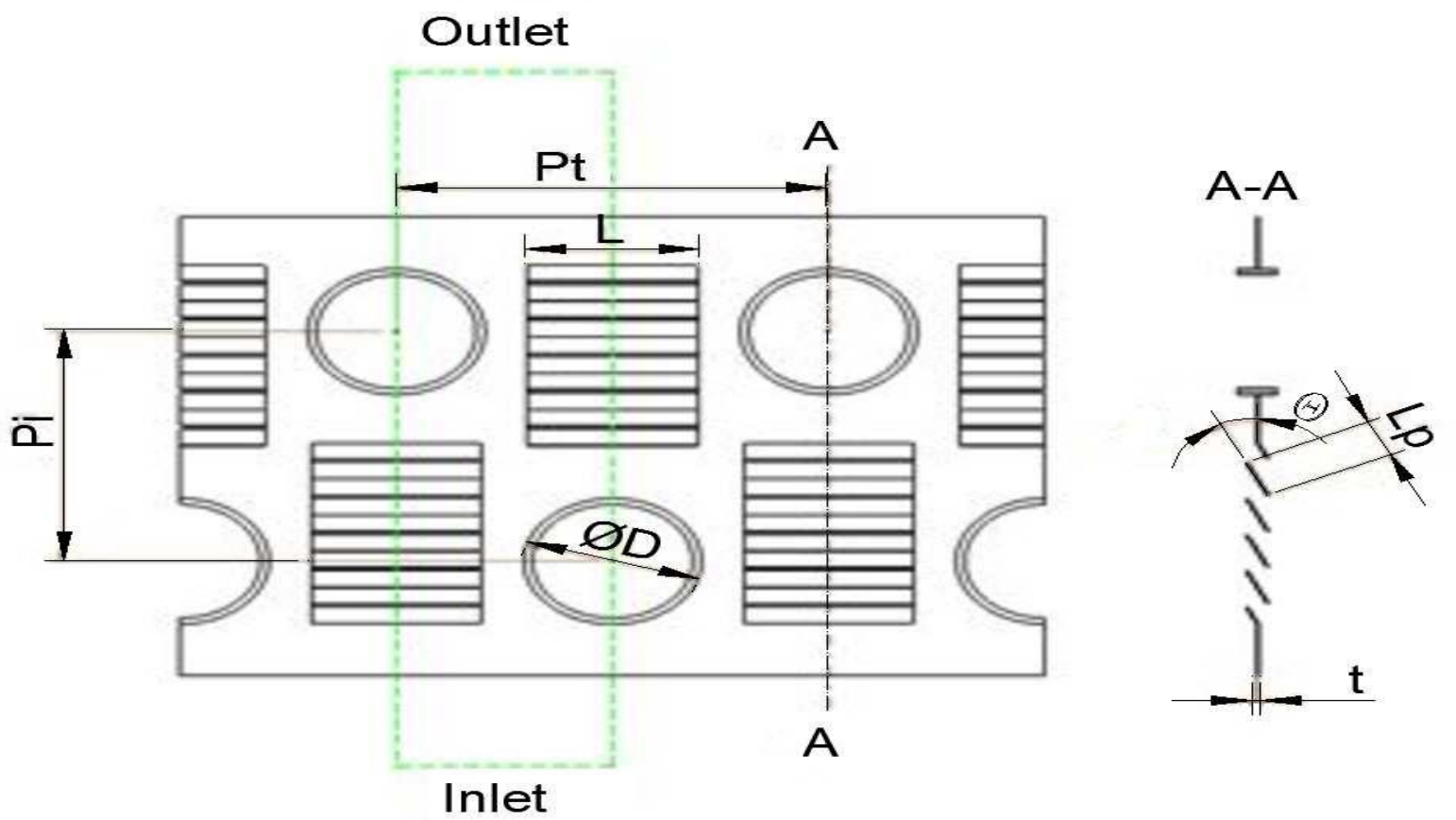

Figure 5: Plane and side visions of louvered fins and explanations of geometric parameters [6].

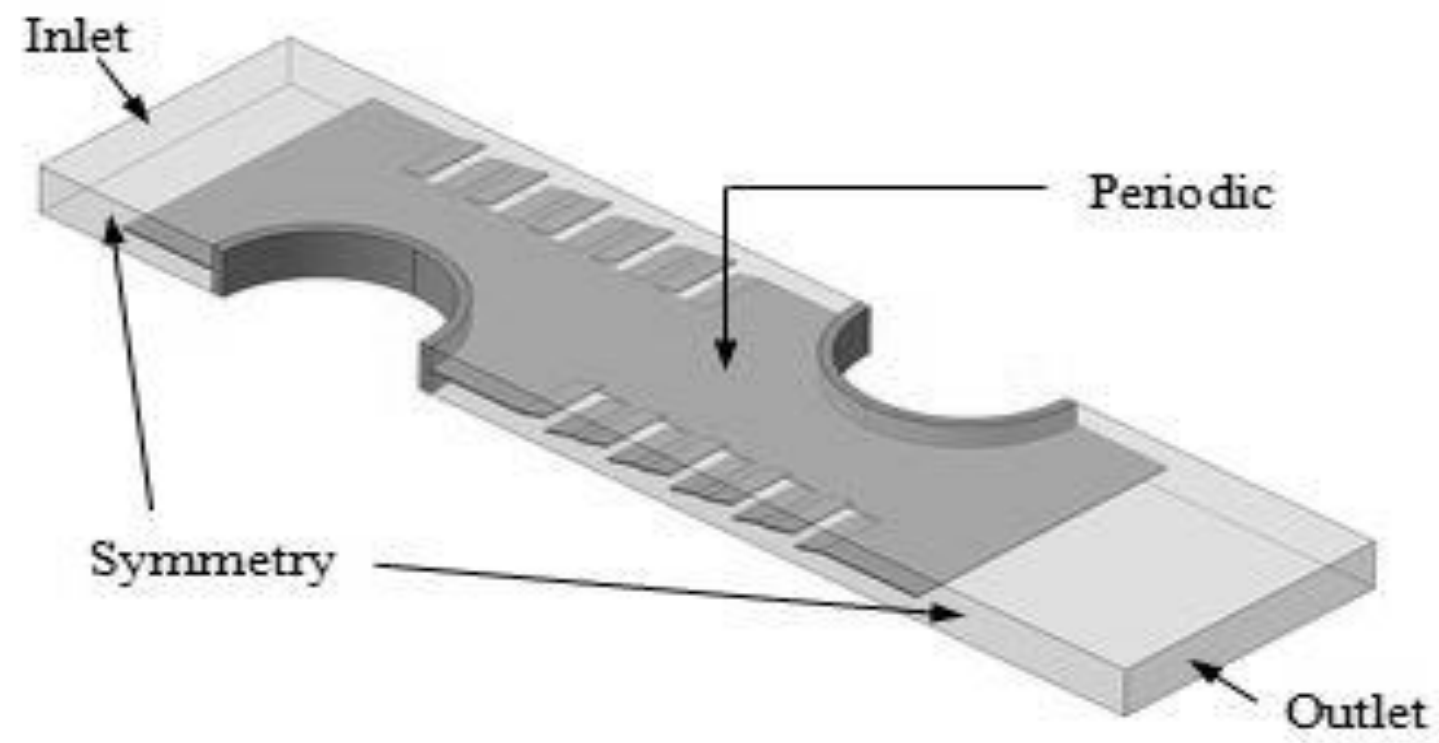

Figure 6: Fluid zone (shaded) round the louvered fin (opaque) [6]. 
All results are showed as a function of the Reynolds number $\mathrm{Re}_{H}$ with the length scale expressed concluded fin pitch. The louvered fin heat exchanger was analysed with fin parameters set as displayed in Table 2 and with the resulting louver constraints $\mathrm{L} / 2=6.25 \mathrm{~mm}, \mathrm{Lp}=3.75 \mathrm{~mm}$, and $\theta=14^{\circ}$. The area-averaged temperature on the episodic surface of the model was used as the fluid bulk temperature (Tb) to control the heat transfer coefficient - the most difficult constraint to evaluate. In Figures 7 and 8the experimental values are indicated with a 10\% comparative error bar to visualize the accordance of the obtained numerical results.

The mathematically projected pressure drop relates strangely well with the experimental results, as seen in the Figure 8. The calculated averaged Nusselt numbers are very comparable to the experimentally acquired values, but over emphasized by almost $10 \%$ over the total range of observed $\mathrm{Re}_{\mathrm{H}}$ numbers showing in Figure 7.

Table 2: The detailed geometry of the examined heat exchangers [6].

\begin{tabular}{|c|c|}
\hline Parameters & Values \\
\hline Tube outside diameter & $10.42 \mathrm{~mm}$ \\
\hline The number of tube row & 2 \\
\hline Longitudinal tube pitch (PI) & $19.05 \mathrm{~mm}$ \\
\hline Transverse tube pitch $(\mathrm{Pt})$ & $25.4 \mathrm{~mm}$ \\
\hline Fin thickness $(t)$ & $0.115 \mathrm{~mm}$ \\
\hline Fin pitch $(\mathrm{H})$ & $2.06 \mathrm{~mm}$ \\
\hline Number of louvers (NI) & 4-5 \\
\hline Louver angle $(\theta)$ & $5-25^{\circ}$ \\
\hline Louver pitch (Lp) & $15 \mathrm{~mm} / \mathrm{N}_{\mathrm{l}}$ \\
\hline Louver length (L) & $4-12 \mathrm{~mm}$ \\
\hline
\end{tabular}

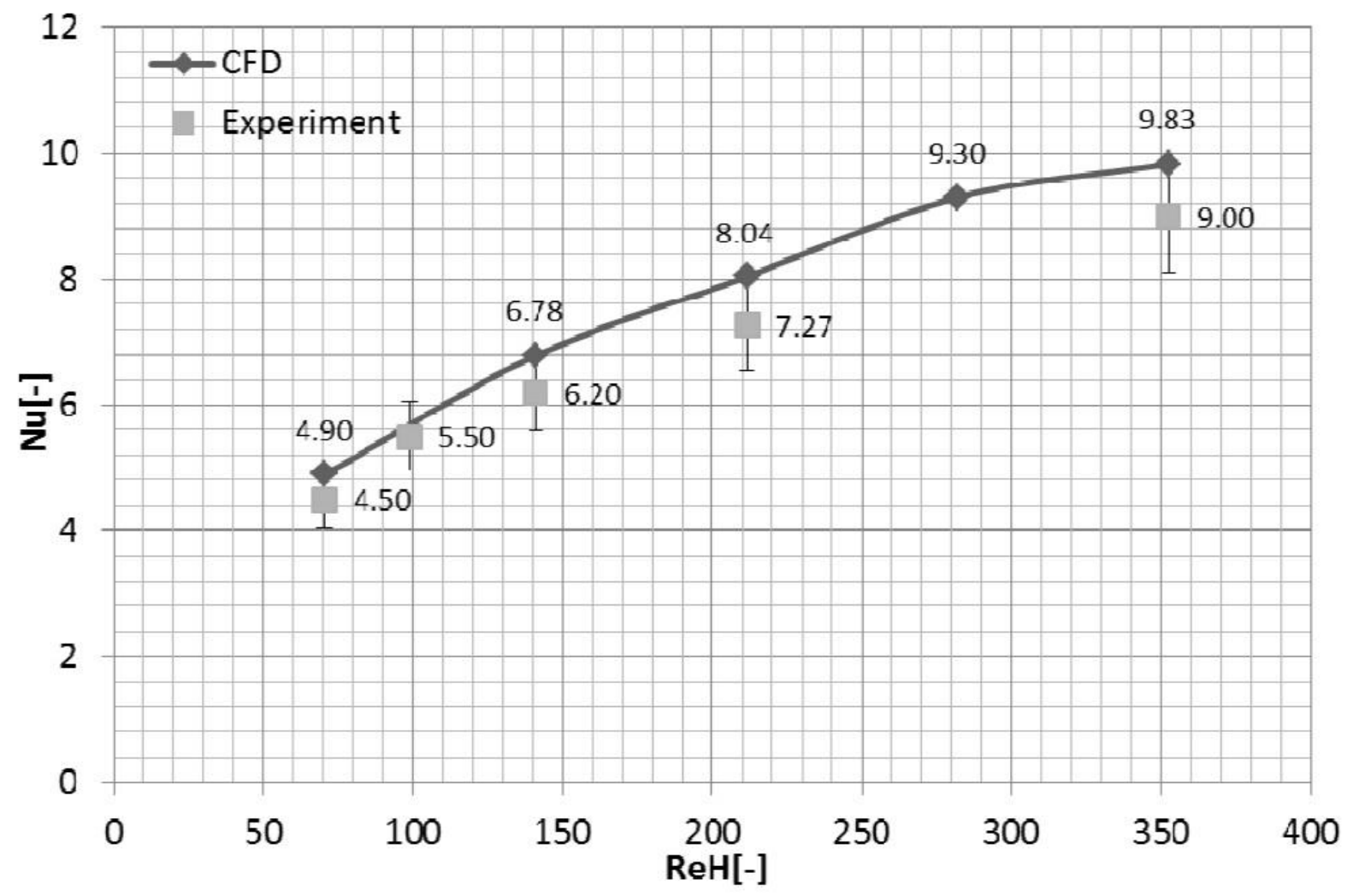

Figure 7: Comparison of numerically \& experimentally achieved average Nusselt number for the louvered fin [6]. 


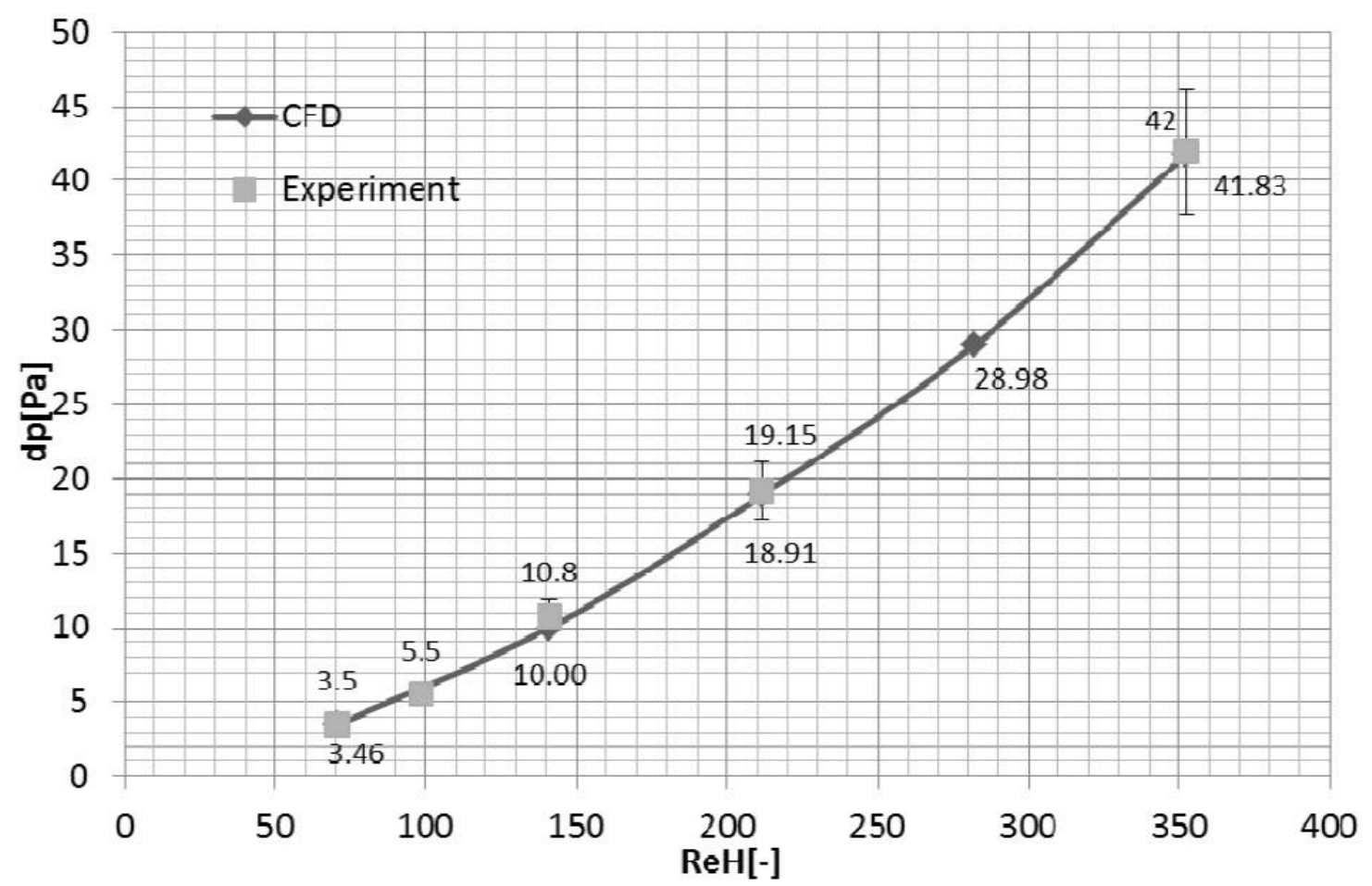

Figure 8: Comparison of numerically \& experimentally achieved average pressure drop for the louvered fin [6].

\subsection{Multi-region louver fins and flat tubes heat exchanger}

Nowadays, well-organized heat exchangers are compulsory for saving energy. Because of high compactness and outstanding heat transmission enactments, the aluminium-brazed heat exchanger with multi-louvered fin and the flat tube is used widely in residential air conditioning systems, automotive, aviation, dynamical machine fields, and so on. Davenport [7, 8], Achaichia [9], Achaichia and Cowell [10] observed air-side heat transfer and flow performance for louvered fin heat exchangers and obtained $j$ and $f$ factors as occupations of the Reynolds number. Huihua and Xuesheng [11] accompanied an investigational study by a scaled-up louvered fin model with dissimilar louver angles and pitches. Their investigational results showed that both the strength of heat transfer and pressure drop improved with growths in oblique angle and plate length. Aoki et al., [12] completed an investigational study on the heat transfer characteristics of dissimilar louver fin ranges such as louver angles and louver and fin pitches, reporting that the coefficients of heat transfer at low air velocity reduced with increasing fin pitch. Rugh et al., [13] calculated heat transfer coefficients and friction losses for high-density louvered fin and flat tube heat exchangers (2000 fins $/ \mathrm{m})$ and suggested $j$ and $f$ correlations. It has been found from their study that a louvered fin heat exchanger formed a $25 \%$ increase in heat transfer and a $110 \%$ increase in pressure drop comparative to a plain fin.

It has been implemented in this experiment on airside heat transmission and pressure drop features of heat exchangers with multi-region louver fins as well as flat tubes on the louvered pitch with Reynolds numbers from 400 to 1600. Figure 9 shows seven types of examples of heat exchangers with a different number of louver regions (0 to 6) and fin louver statures were verified.

The $\mathrm{j}$ factor and $\mathrm{f}$ factor tend to reduce with an increasing Reynolds number and tend to rise with the enlarged number of louver regions. The cause is that with the increased number of louver regions, the louver area of the fin rises. The results show that the louver fin with 4 regions and the louver fin with 6 regions are far better than the conventional fin in overall performance. At the same time, the louver fin with 6 regions is also better than the louver fin with 4-regions.

\subsection{Multi-louvered fin and flat tube heat exchanger}

An accurate valuation of probable air-side heat transfer surface geometries is a prerequisite for the best possible heat exchanger plan. A simplified and translucent analytical procedure for the evaluation of multi louvered fin and flat tube heat exchanger geometries that permit maximal performance for given borderline conditions has been developed [15]. Figure 10 shows a schematic diagram of the test apparatus used in the study. The construction of this test apparatus contains a suction type wind tunnel, heat transfer fluid as water movement and control units, and a data acquirement system and is located in a continuous temperature and moisture compartment. 

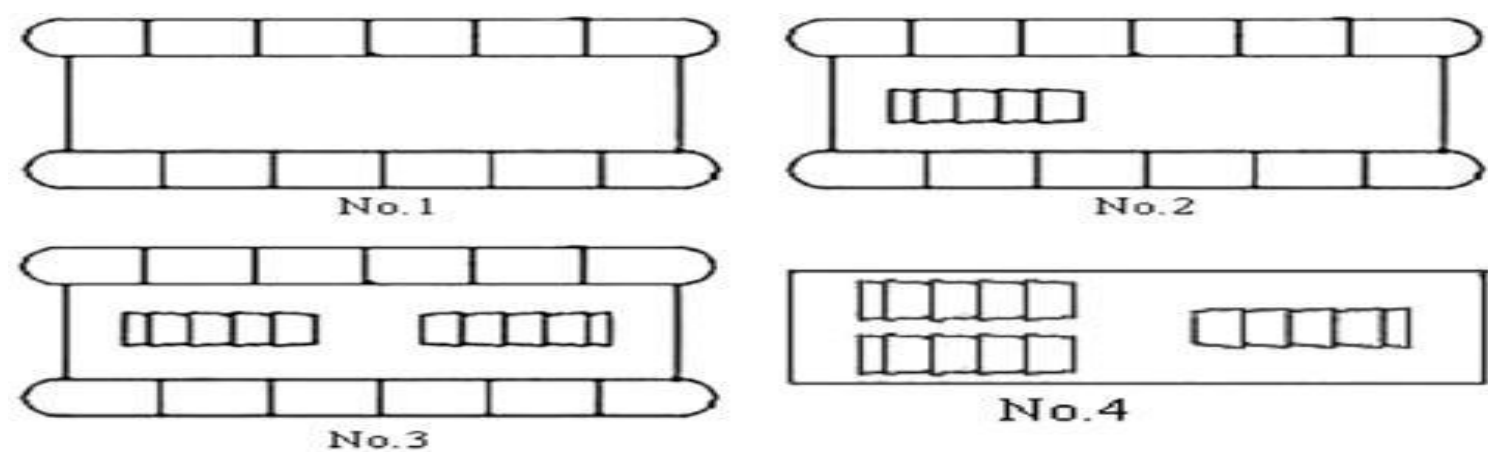

$\mathrm{No} .4$
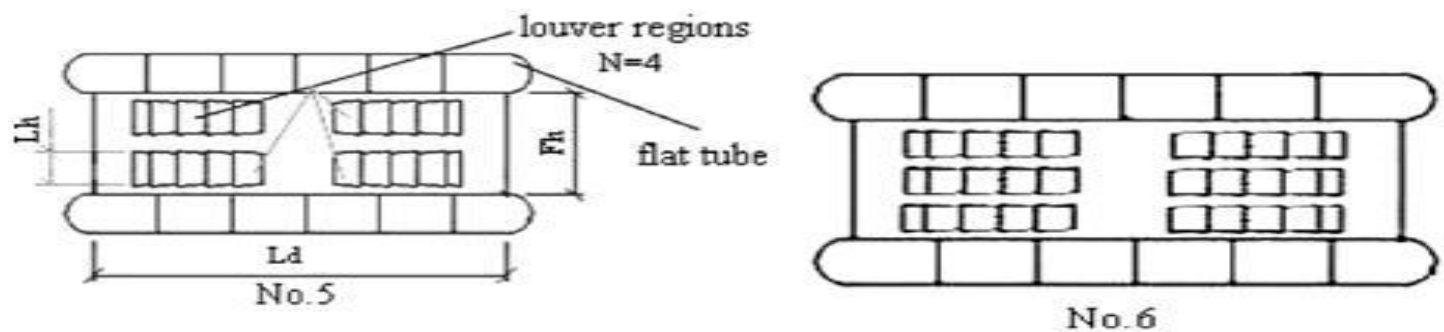

conventional fin

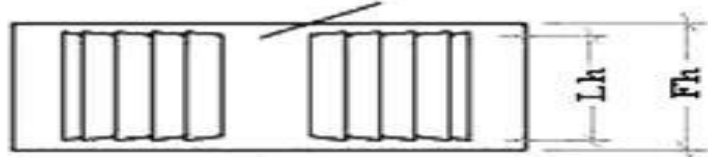

No.7

Figure 9: Multi region louver fin patterns [14].

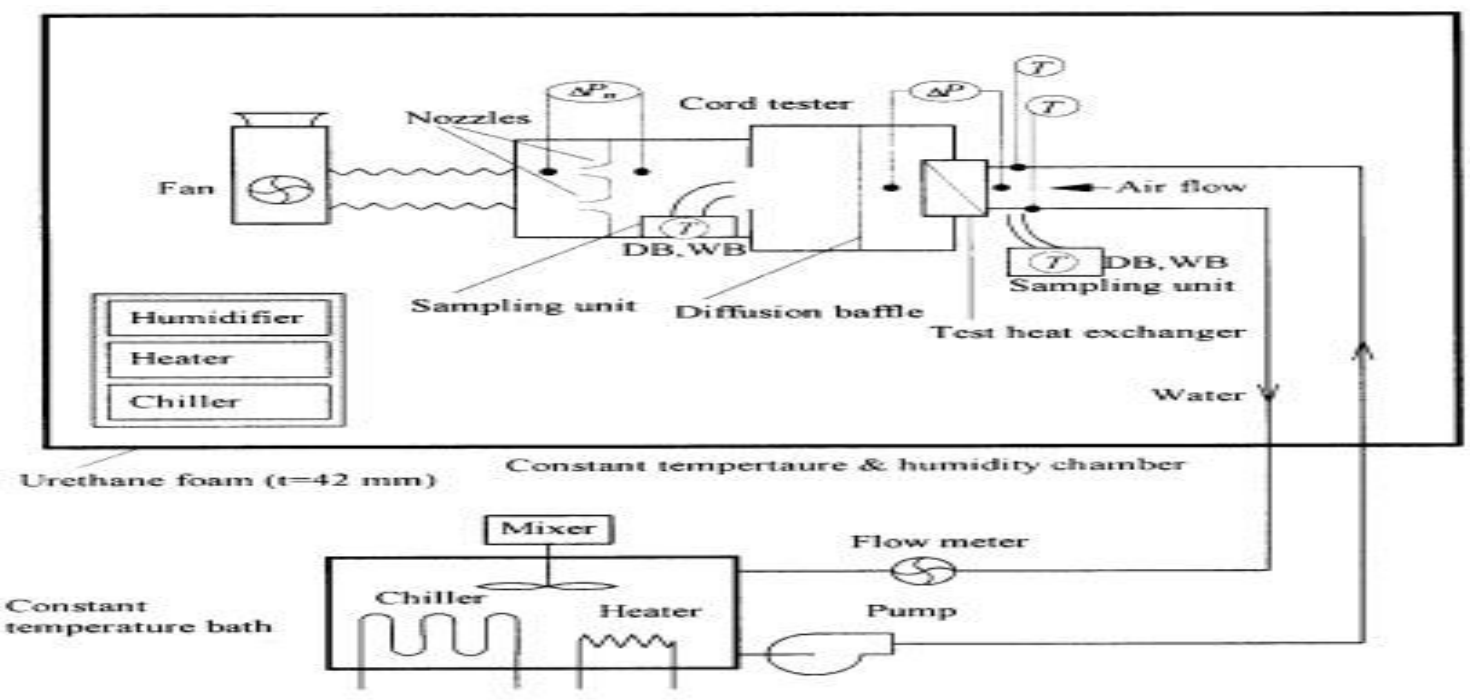

Figure 10: Schematic diagram of the test apparatus [16].

The study has been stated with investigate on the side of air in heat transfer as well as pressure fall features for the heat exchangers of multi louvered fin and flat tube. Here the air adjacent thermal enactment data has analysed using the effectiveness- NTU method for cross-flow heat exchanger. Here when using $16 \mathrm{~mm}$ flow depth then the heat transfer coefficients does not change more with respect to louver angle. In the other term, if used $24 \mathrm{~mm}$ flow depth then heat transfer coefficients increase with louver angle and extreme at $27^{\circ}$, and again fall with louver angle. The Friction factors are increased with louver angle and the $j$ factor increased with louver angle, but its effect on the $j$ factor differs with flow depth. 


\section{INCLINED LOUVERED FINS}

\subsection{Inclined louvered fin heat exchanger}

Air conditioning has evolved from a luxury item into a standard appliance during the past decades. At first, these units could only be found in office buildings, airports, supermarkets, etc. but now the main market for the air conditioning manufacturers in the domestic one. Sales in this market have seen tremendous growth, no doubt due to the string of hot summers in Europe and the United States, as well as to the continuous drop in price for this product. At this moment, about $80 \%$ of all US homes use air conditioning during the summer to improve domestic comfort [17]. The heat exchanger used in this research is part of a commercially available air conditioning unit and has continuous fins. The measurements were taken at solid-state conditions. Through the measurements, the inlet temperature of the water varied faintly (temperature drop of $\pm 1^{\circ} \mathrm{C}$ ). This temperature was measured by a PIDcontroller. Once the motionless command was achieved, the rail was positioned behind the tubes. For each tube a series of 10-15 samples were taken and this for 15 second. During these samples, the signal of the water flow meter was logged continuously. In Figure 11 measurements can be seen. All constraints of the current fin plan are fine within the sort of the verified examples, excepting the longitudinal fin pitch $(22 \mathrm{~mm})$ which is just outside the range (12.4 $27.5 \mathrm{~mm}$ ). From Figure 11 it is strong that the external convective heat transfer coefficient is on average 2.3 times higher than that for a plain fin (reaching from 2.15 for small Reynolds numbers to 2.5 for high Reynolds numbers). As the Reynolds number rises the flow becomes more turbulent (an indorsing combination of the bulk flow with the border layers) and the border layers become thinner. As a result, the flow can pass through the gaps between the different louvers and transferable louvers. Both effects supplement the heat transmission. For great Reynolds numbers, the difference is about 10\%. For Reynolds numbers lower than 1000, the correlation lies within the error margin of the measured values. For low Reynolds numbers, it can therefore be decided that there is no solid dependence on the louver and tube bank constraints.

For the higher Reynolds numbers, the difference increases, indicating the rising importance of parameters not present within the correlation. It is clear that the much smoother profile (fewer protruding edges in the flow path) as studied by will induce less vortex detaching then the profile studied here. Of course, it must be prominent that no clear choice of validity can be proven for this correlation, as it was determined using samples with a continuous transversal and longitudinal fin pitch. Therefore, additional research is compulsory to inspect the effect of various parameters (high Reynolds numbers versus low Reynolds numbers). The current research focused on Reynolds numbers fluctuating from 250 to 1300 . This corresponds to an inlet velocity of $0.5-2.8 \mathrm{~m} / \mathrm{s}$. This heat exchanger usually functions amongst $0.95 \mathrm{~m} / \mathrm{s}$ and $1.7 \mathrm{~m} / \mathrm{s}$, so the operating range is well covered. Measurements were taken to a Reynolds number as low as 100, the sharp drop in convection coefficient measured for Reynolds numbers between 100 and 250 is probably due to a combination of these effects. More study is required to improve understanding for this low Reynolds area. The friction characteristic was fixed using a series of differential pressure measurements. The pressure drop was measured for a range of Reynolds numbers. The resulting error is shown as well in Figure 12. The results were associated with the correlation for plain fins [18]. This correlation predicts for great Reynolds numbers a friction factor only $10 \%$ lesser than the dignified values.

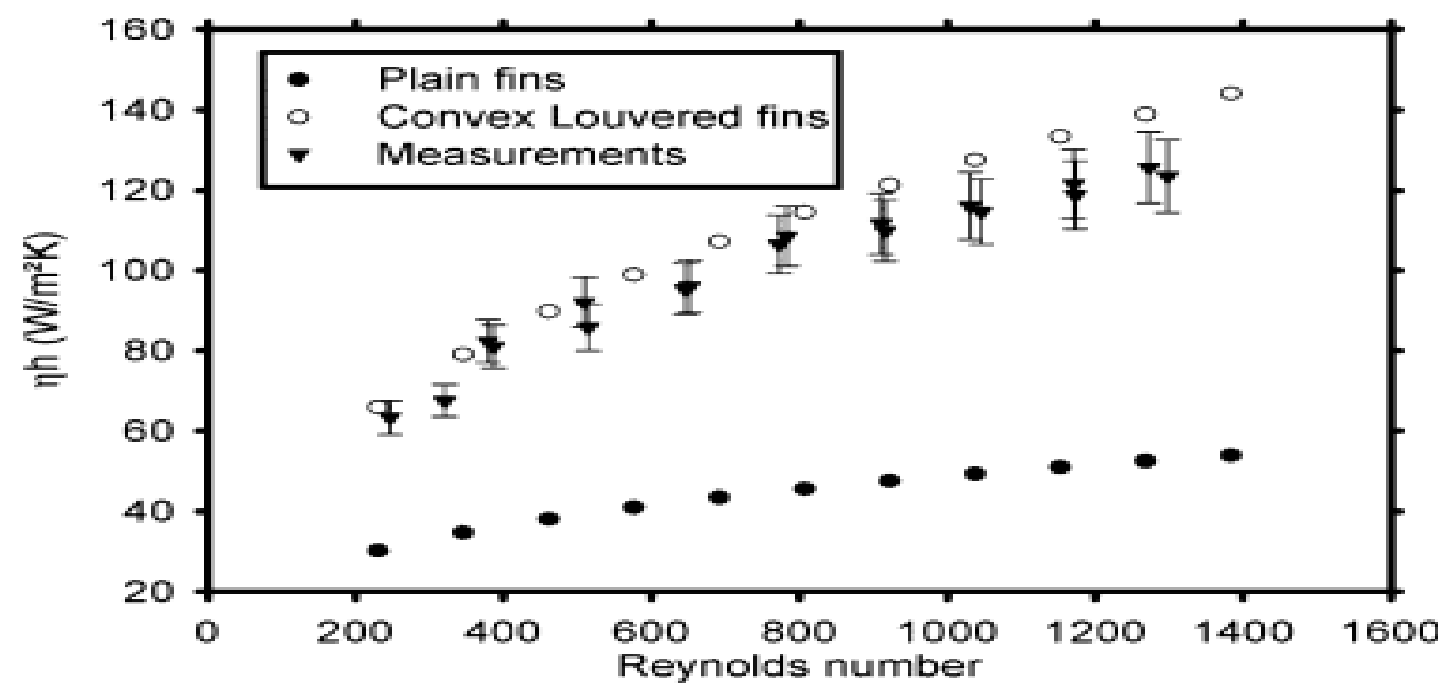

Figure 11: Reserved values of Colburn factor versus air side Reynolds number compared to forecast values by the correlation for plain fins and the correlation for convex louvered fins [18]. 


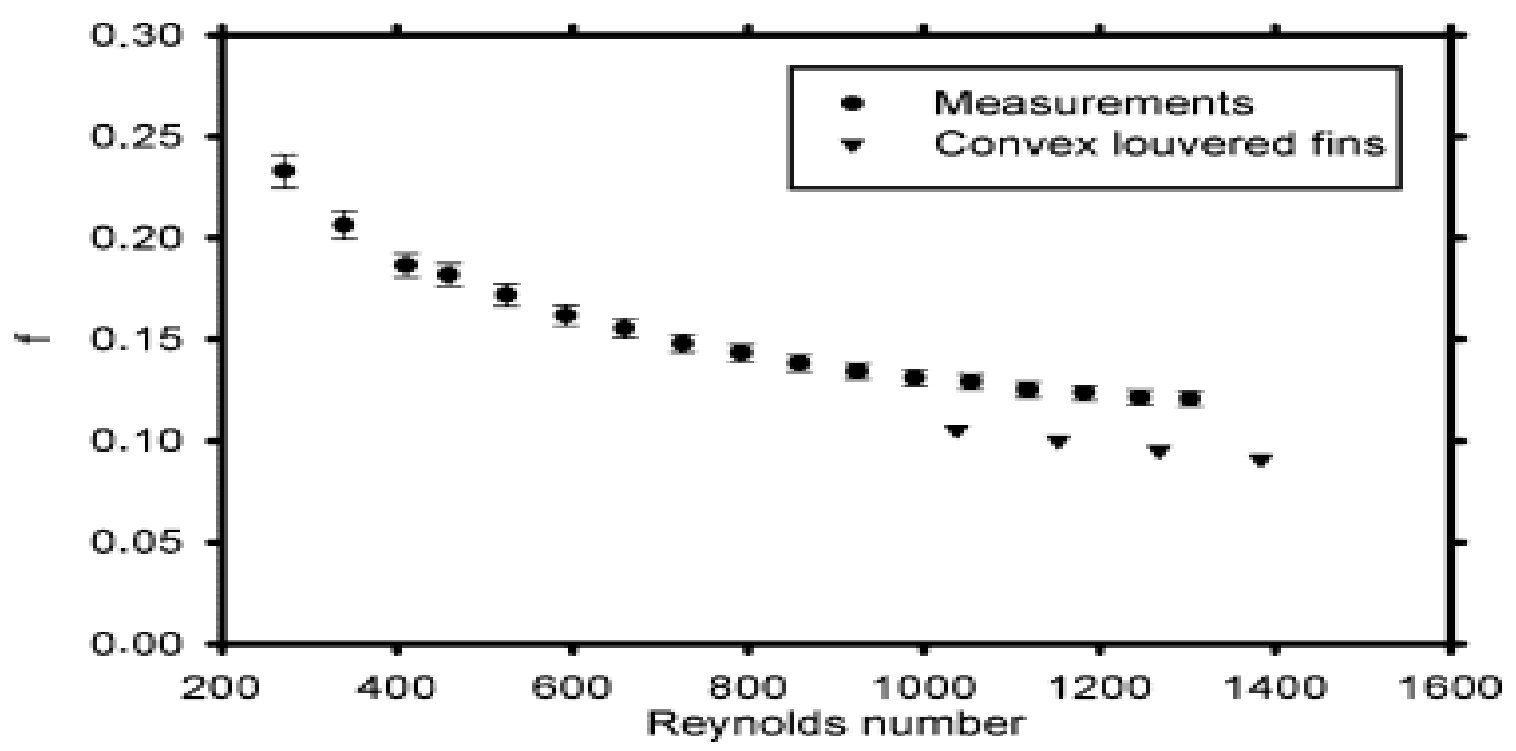

Figure 12: Restrained values of friction factor against air side Reynolds number compared to expected values by the correlation for convex louvered fins $(\mathrm{Re}>1000)$ [18].

For the small Reynolds numbers, the plain fin correlation forecasted friction factors up to $77 \%$ larger than the calculated values. This specifies that the connection for plain fins cannot be used for comparison, as the longitudinal tube pitch lies outside the range of verified parameters. If the correlation distributed for Reynolds numbers greater than 1000 are estimated for lower Reynolds numbers, the two friction curves remain to parallel up to a Reynolds number of 800, after which they diverge. The fin has a clearly more open construction than the previously established type (by using louvers in its place of $\mathrm{V}$-shaped interruptions channels are designed allowing for the flow to permit more easily), which should decrease the pressure drop. Nevertheless, the better disposition results in larger recirculation zones, and the mirrored rearrangement louvers increase form drag. As renowned, the correlation of disregards fin parameters and was built using samples having quite different parameters, so it is difficult to control the range of its validity [18].

\subsection{Variable louver angle heat exchanger}

For a typical fin-and-tube heat exchanger, the controlling thermal resistance is generally on the air or fin side. Therefore, to efficiently recover the complete enactment of the heat exchanger, highly enhanced surfaces on the fin side are often fulfilled in the application. Webb [19] delivers a review of the printed data and correlations. Louver fin geometry is used extensively for heat transmission to the air in automotive and room air conditioning heat exchangers such as radiators, condensers, and oil coolers. The first dependable printed data on louvered fin surfaces was in 1950 by Kays and London [20]. In the 1980s, Davenport [21, 22] worked with smoke trace studies on a tentime scale model of a non-standard variant of the crenulated louvered fin geometry and established the heat transfer and friction correlations for the crenulated louvered fin geometry. Webb and Trauger [23] worked with visualization techniques to investigate the link between the flow arrangement and the geometrical parameters of the louver angle, louver pitch, and fin pitch. It was found that the degree of flow alignment at a given Reynolds number is improved as the fin-to-louver pitch ratio is reduced. Jang et al., [24] mathematically examined three-dimensional convex louver finned-tube heat exchangers. The effects of different geometrical parameters, including convex louver angles $(\mathrm{h}=$ 15.5, 20.0, 24.0), louver pitch ( $\mathrm{Lp}=0.953 \mathrm{~mm}, 1.588 \mathrm{~mm}$ ), and fin pitch (8 fins/in., 10 fins/in., 15 fins/in.) are examined in detail for the Reynolds number $\mathrm{Re}_{\mathrm{H}}$ ranging from 100 to 1100 . It was presented that, for equal louver pitch, both the average Nusselt number and pressure drop coefficient are improved as the louver angle is improved; while for equal louver angles, they are reduced as the louver pitch is improved. In this study, the 3-D thermalhydraulic examination with movable louver angle of louver fins heat exchangers. It has been tested five models (AE) having continuously improved or reduced louver angle patterns. In Figure13the case models of verified heat exchangers. The heat transfer and pressure drop appearances for different models construed by Colburn factor $\mathrm{j}$ and friction factor $\mathrm{f}$. 


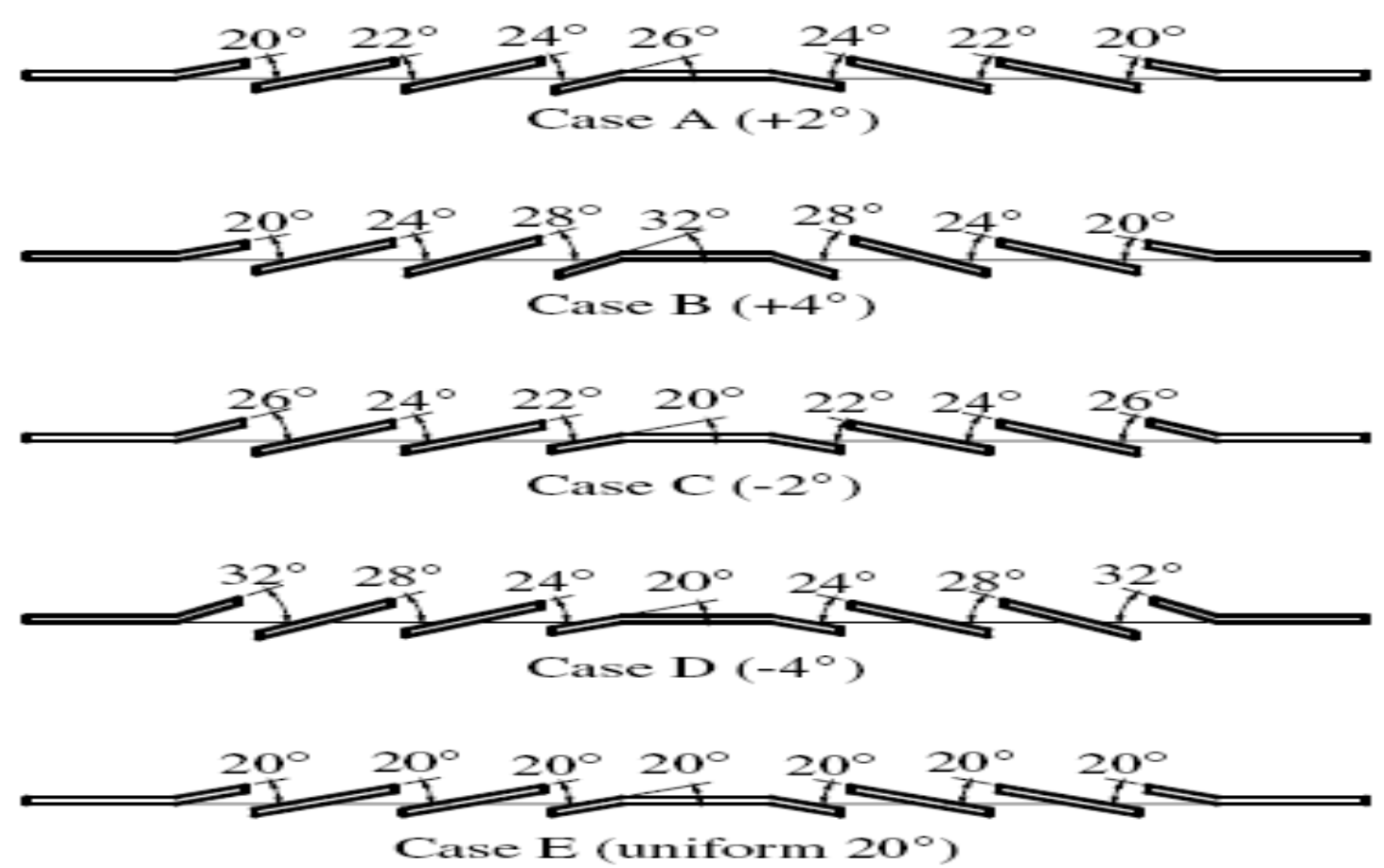

Figure 13: Different case models of heat exchanger [25].

It has been seen from this study that at Reynolds number 1075, the temperature gradient is more distinct for larger louver angle that is the greater heat transfer performance for large louver angle. Nevertheless, a greater louver angle would also donate to the rise in the pressure drop. It is also found that the temperature gradient is higher for sequentially variable louver angles than identical angles. It is also showed that together Nusselt number $\mathrm{Nu}$ and pressure drop coefficient $C p$ for continually movable louver angles (cases A-D) are higher than those for the identical louver angle (case E). It is seen that border layers exist on both the upper and lower faces of the louvers at Reynolds number 1075. The significant heat transfer improvement is due to stripper boundary layers that form at the leading edge of each louver. The current results indicated the consecutively variable louver angle patterns applied in heat exchangers could effectively improve the heat transfer presentation.

\section{VORTEX GENERATORS}

\subsection{Delta winglet vortex generators}

Every day large amounts of heat are transferred in many industrial and domestic processes. As a result, any performance increase of the heat transfer will have a significant impact on energy use, fuel consumption, and the resulting greenhouse gas emissions. More energy-efficient heat exchangers like Louvered fin and round tube heat exchangers thus help to meet the 20-20-20 climate and energy targets set by the European Union [26]. In this procedure, the mentioned geometry with vortex generator is shown in Figure 14. The flat landing stage and evolution part are chosen as the span wise dimensions of in [27], as $0.25 \mathrm{Lp}$ for the smallest flat landing and 0.5Lp for the transition part. Episodic settings are applied on both sides of the domain as well as on the top and bottom. The height of the computational domain is equal to the fin pitch Fp and the width is equal to transversal tube pitch Pt. The fin surface is positioned in the centre with half fin positioning beyond the fin surface and half fin spacing underneath. The entry length upstream of the fin equivalents to 5 times the fin pitch Fp and the dominion prolongs 7 times the tube diameter Do downstream of the fin.

The sizes of the multifarious heat exchanger are listed in Table 3. The louver geometry, tube diameter, and tube pitches are nominated from the databank with louvered fin heat exchangers provided. The results are designed in Figure 15. For the highest Reynolds numbers the simulated friction factors do not fall within the uncertainty of the experimental measurements: the maximum over prediction is $10 \%$. In general, there is an acceptable match between the simulations and the experiments within the considered uncertainty ranges (the mean deviation of the Colburn jfactors is $6.2 \%$ and of the friction factors $5.5 \%$ ).

The Colburn j-factors and friction factors are designed for the purpose of the Reynolds number $\operatorname{Re}_{\mathrm{Dh}}$ in Figure 16. The Reynolds number range 140-1220 matches up to inlet velocities of $0.63-5.25 \mathrm{~m} / \mathrm{s}$. Figure $16(\mathrm{a})$ illustrates that the Colburn j-factor rises when delta winglets are used. The maximum increase is $16 \%$ compared to the baseline geometry (at $\mathrm{Re}_{\mathrm{Dh}}=600$ ). However, as is clear from Figure $16(\mathrm{~b})$, the delta winglets also cause a penalty in friction factor (up to $35 \%$ at the largest Reynolds number $\left(\operatorname{Re}_{\mathrm{Dh}}=1220\right)$ ). 
Table 3: Size dimensions of the multifarious heat exchanger (DW = delta winglet) [27].

\begin{tabular}{|l|c|c|}
\hline \multicolumn{1}{|c|}{ Parameters } & Symbol & Value \\
\hline Outer tube diameter & $\mathrm{D}_{\mathrm{o}}(\mathrm{mm})$ & 6.75 \\
\hline Fin thickness & $\mathrm{t}_{\mathrm{f}}(\mathrm{mm})$ & 0.12 \\
\hline Louver pitch & $\mathrm{L}_{\mathrm{p}}(\mathrm{mm})$ & 1.50 \\
\hline Louver angle & $\theta\left(^{\circ}\right)$ & 35 \\
\hline Fin pitch & $\mathrm{F}_{\mathrm{p}}(\mathrm{mm})$ & 1.71 \\
\hline Transversal tube pitch & $\mathrm{P}_{\mathrm{t}}(\mathrm{mm})$ & 17.6 \\
\hline Longitudinal tube pitch & $\mathrm{P}_{\mathrm{l}}(\mathrm{mm})$ & $0.5 \mathrm{D}_{\circ}$ \\
\hline Stream wise delta winglet position & $\Delta \mathrm{x}(\mathrm{mm})$ & $\pm 0.3 \mathrm{D}_{\circ}$ \\
\hline Span wise delta winglet position & $\Delta \mathrm{z}(\mathrm{mm})$ & 35 \\
\hline DW angle of attack & $\alpha\left({ }^{\circ}\right)$ & $0.9 \mathrm{~s}$ \\
\hline DW height & $\mathrm{h}(\mathrm{mm})$ & $2 \mathrm{~h} ; 1.5 \mathrm{~h}$ \\
\hline DW base & $\mathrm{b}(\mathrm{mm})$ & \\
\hline
\end{tabular}

(a)

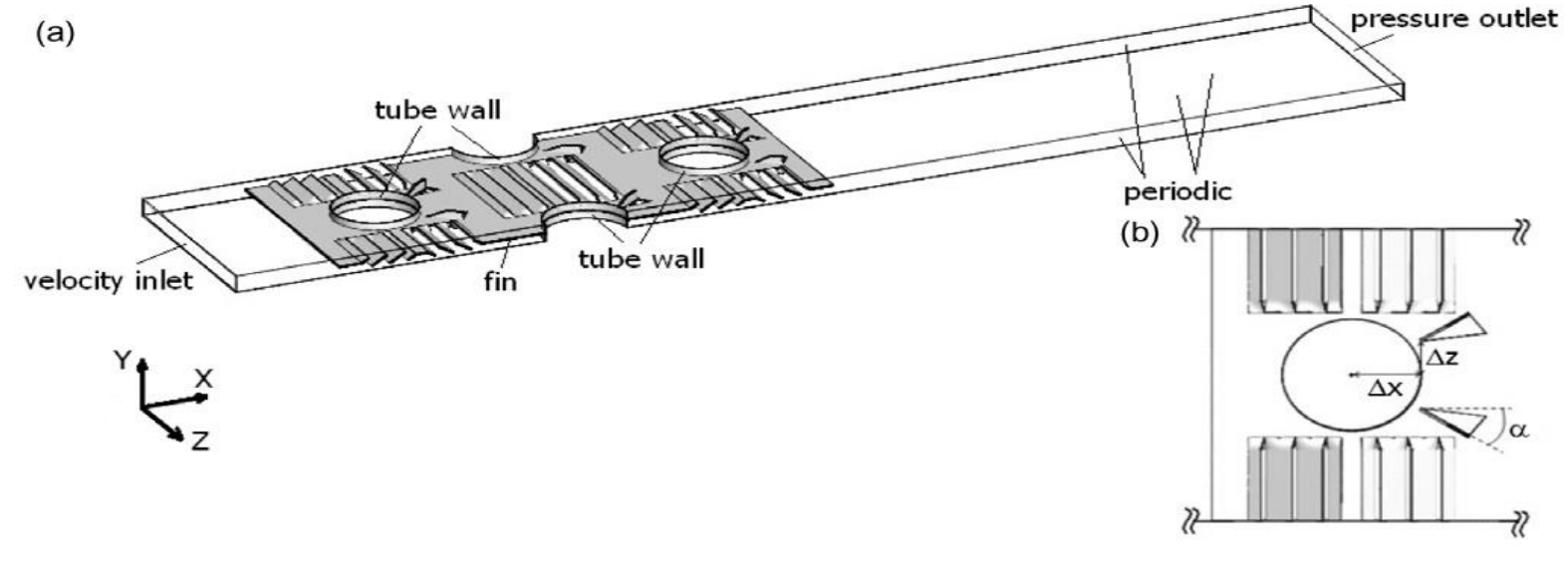

Figure 14: (a) three-dimensional computational domain\& (b) top view showing the delta winglet position [27].
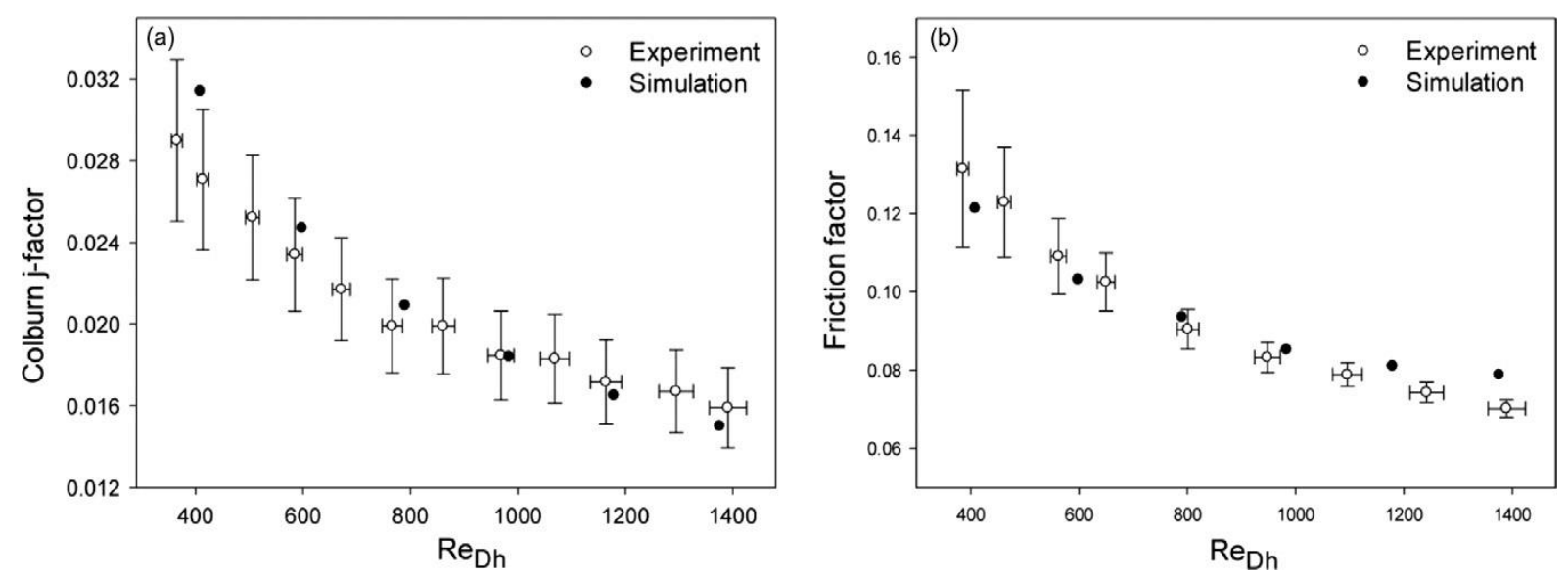

Figure 15: Comparison between the experimental data and the simulation results: (a) Colburn j-factors and (b) friction factors [27]. 

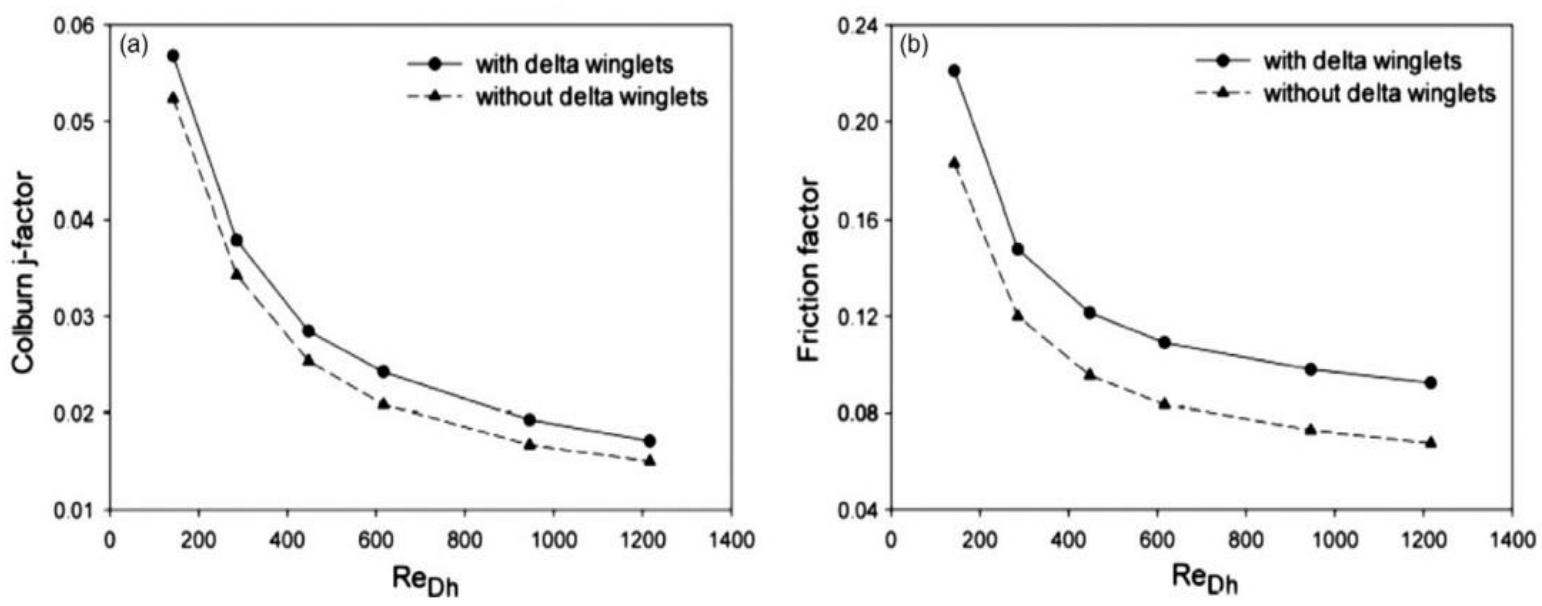

Figure 16: Comparison of (a) the Colburn j-factor and (b) the friction factor for the baseline geometry without delta winglets and the compound design with delta winglets [26].

\section{COMPACT HEAT EXCHENGER}

\subsection{Compact Heat Exchanger with Louvered Fins}

As the demand for heat exchangers is rapidly increasing by production industries that are more capable, compact, and less costly, heat transfer enhancement has multiplied with great impetus. Thus, engineers come out with one wonderful solution, at which one revolution device has been developed decades ago called compact heat exchanger $(\mathrm{CHE})$. Hence, Compact heat exchangers are capable to transfer further energy in a very limited cost method than other types of heat exchangers with more energy-saving when compared to conventional technology [19, 28-29]. This study enclosed the examination, imitation, and the investigation of modifications in geometrical factors modifications of louvered fin compact heat exchanger, CHE. Figure 17 shows the physical prototypical and computational dominion for the louvered fin $\mathrm{CHE}$. For simple evidence, louver design is usually a design like a window with plane slats at which each one of the quadrilateral platters from Figure 17 is considered with some disposition angles. This louver design is used alongside the fin of the CHE. In every coating of the fin, the configuration is planned as in Figure 18 to develop the performance of heat elimination as the fin design plays the prime role in creating the utmost efficiency of the CHE. Also, the movement for each instance will be presumed as a laminar flow for inlet air velocity ranged from $0.3 \mathrm{~m} / \mathrm{s}$ to $15 \mathrm{~m} / \mathrm{s}$. As for this study, the enactment of louvered fin $\mathrm{CHE}$ on the thermal and hydraulic investigation is estimated by variable louver angle and fin pitch.

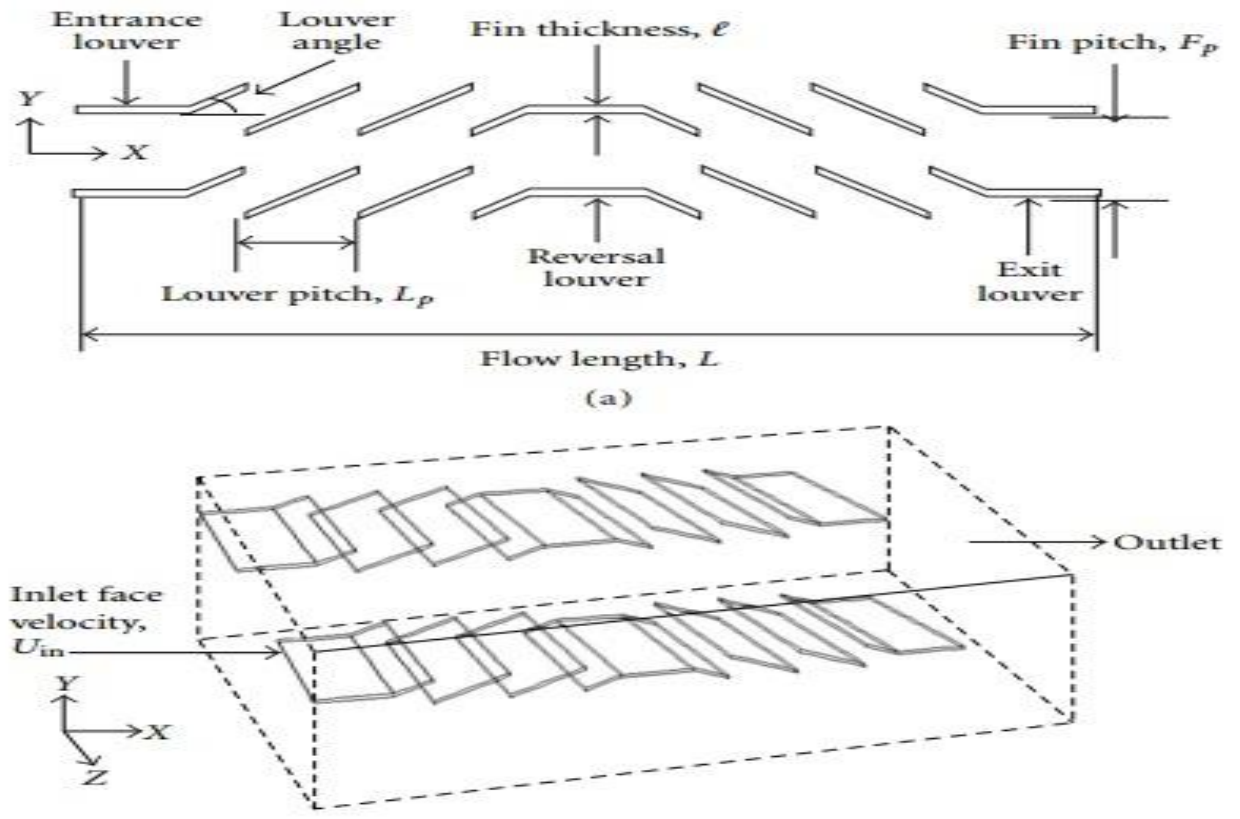

Figure 17: (a) The physical model (2D view in X-Y plane) and (b) computational domain [30]. 


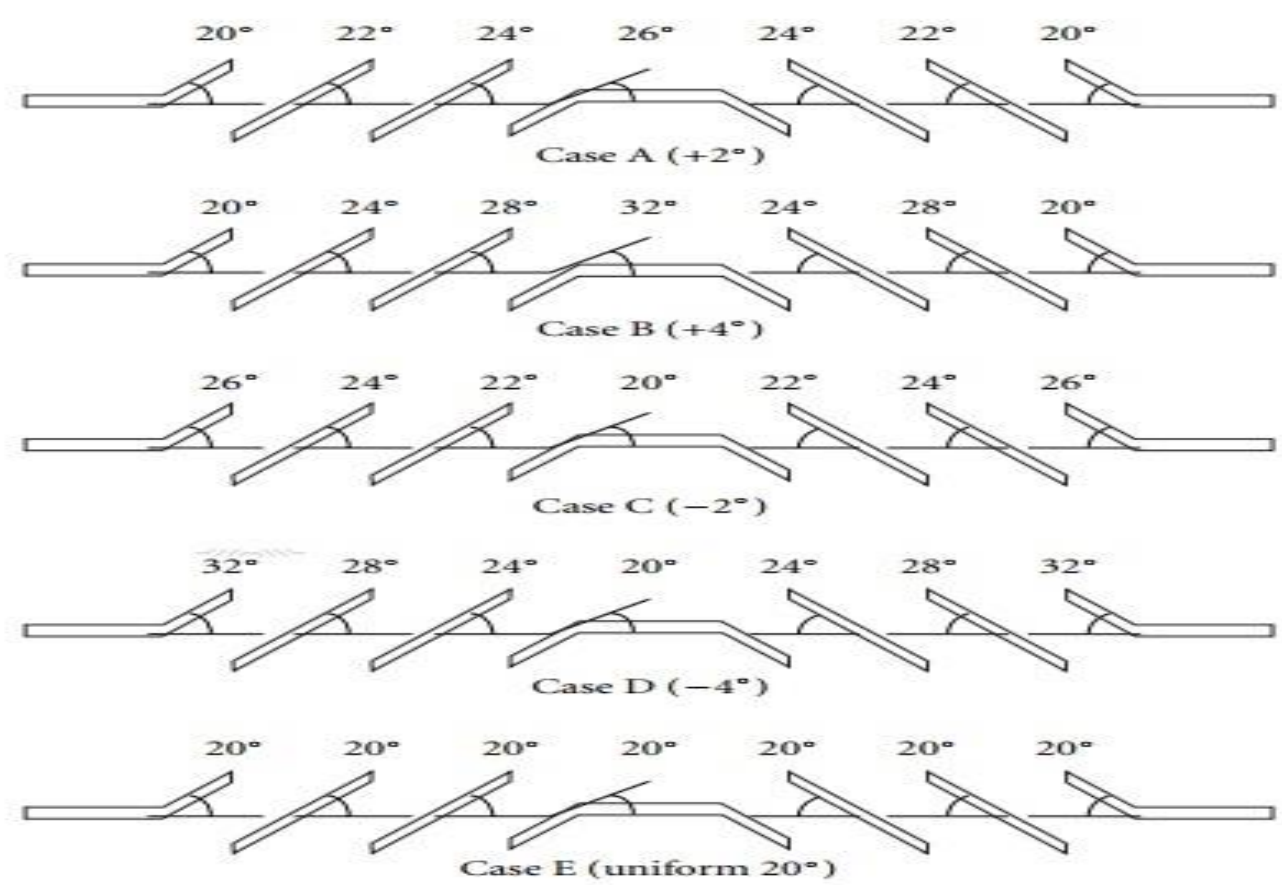

Figure 18: Five altered cases of consecutively improved and reduced louver angle $\left(+2^{\circ},+4 \circ,-2^{\circ},-4^{\circ}\right.$, and uniform angle 20॰) [30].

To examine the effect of fin pitch on heat transfer performance of louvered fin CHE, the louver angle selected is immovable at 20 . throughout along the fin but the fin pitch is now selected to be movable. It consists of three variables which are

(1) case A (fin pitch $=1.0 \mathrm{~mm}$ );

(2) case $B$ (fin pitch $=2.0 \mathrm{~mm}$ );

(3) case $C$ (fin pitch $=4.0 \mathrm{~mm}$ ).

For each situation, the other measurements of the $\mathrm{CHE}$ are being permanent as indicated below.

Louver-pitch $(1.00 \mathrm{~mm})$;

Fin-thickness (0.05 mm);

Flow-length $(9.00 \mathrm{~mm})$;

Inlet air temperature (Tin) $\left(20^{\circ} \mathrm{C}\right)$;

Inlet air pressure (Pin) $(0.0 \mathrm{~Pa})$;

Fin wall temperature $(\mathrm{Tw})(60 \circ \mathrm{C})$;

Frontal-velocity (Uin) $(0.3 \sim 15 \mathrm{~m} / \mathrm{s})$;

Louver-angle (uniform angle of 20 );

For all circumstances of louvered fins of $\mathrm{CHE}$ considered, it is observed that the higher temperature section arises nearby the louvers at flow presence while the smallest temperature occurs in the region near the flow arrival regions. Figure 19 shows the temperature supply of constant louver angle (20.) with fin pitch of $1 \mathrm{~mm}$ (case A) at $\operatorname{Re}=500$ renderings to the occurrences defined above. Therefore, greater heat transfer performance is expected for a louvered fin with minor pitch.

It may be presumed from Figure 20; that the lowest fin pitch (case A) produces greater values of Nu compared to case $B$ and $C$. The reason why louvered fin with minor pitch provides improved heat transfer performance equated to the larger one is that the louver with minor pitch caused more turbulence inflow of the working fluid and the border layer comparative to the fundamental flat-plate surfaces [30]. 

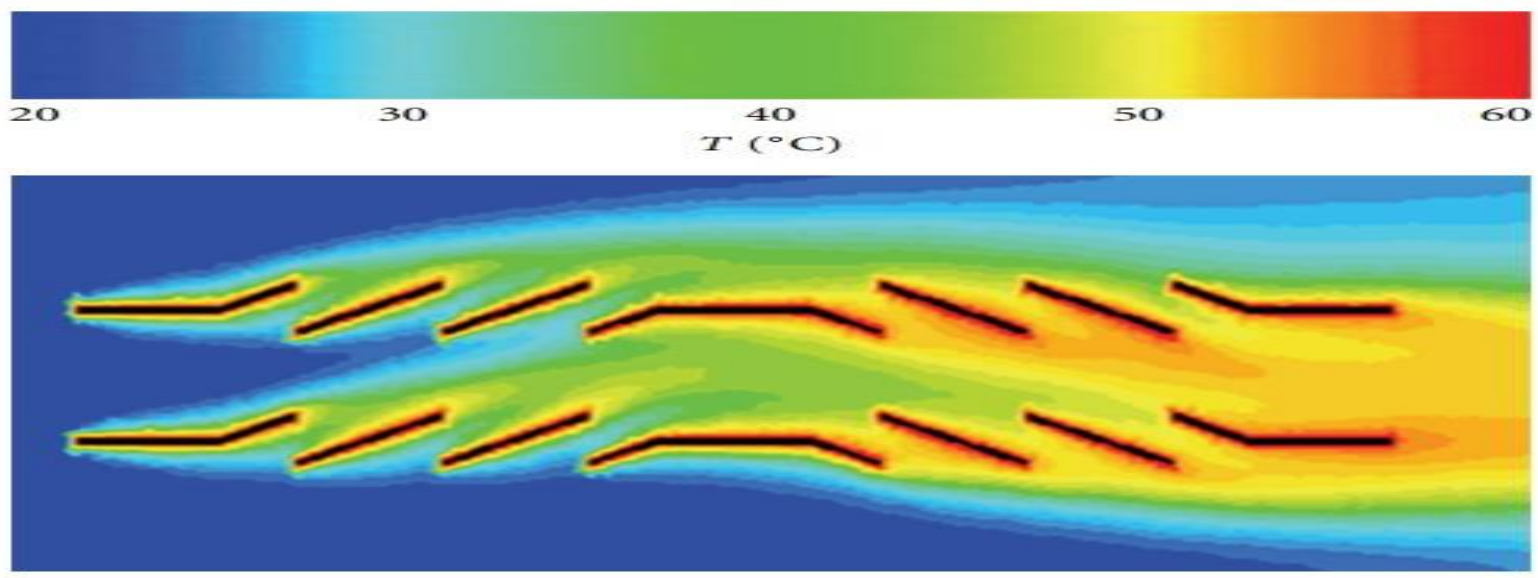

Figure 19: Temperature delivery along the flow direction for identical louver angle (20॰) with fin pitch of $1 \mathrm{~mm}$ (case A) and $\operatorname{Re}=500$ [30].

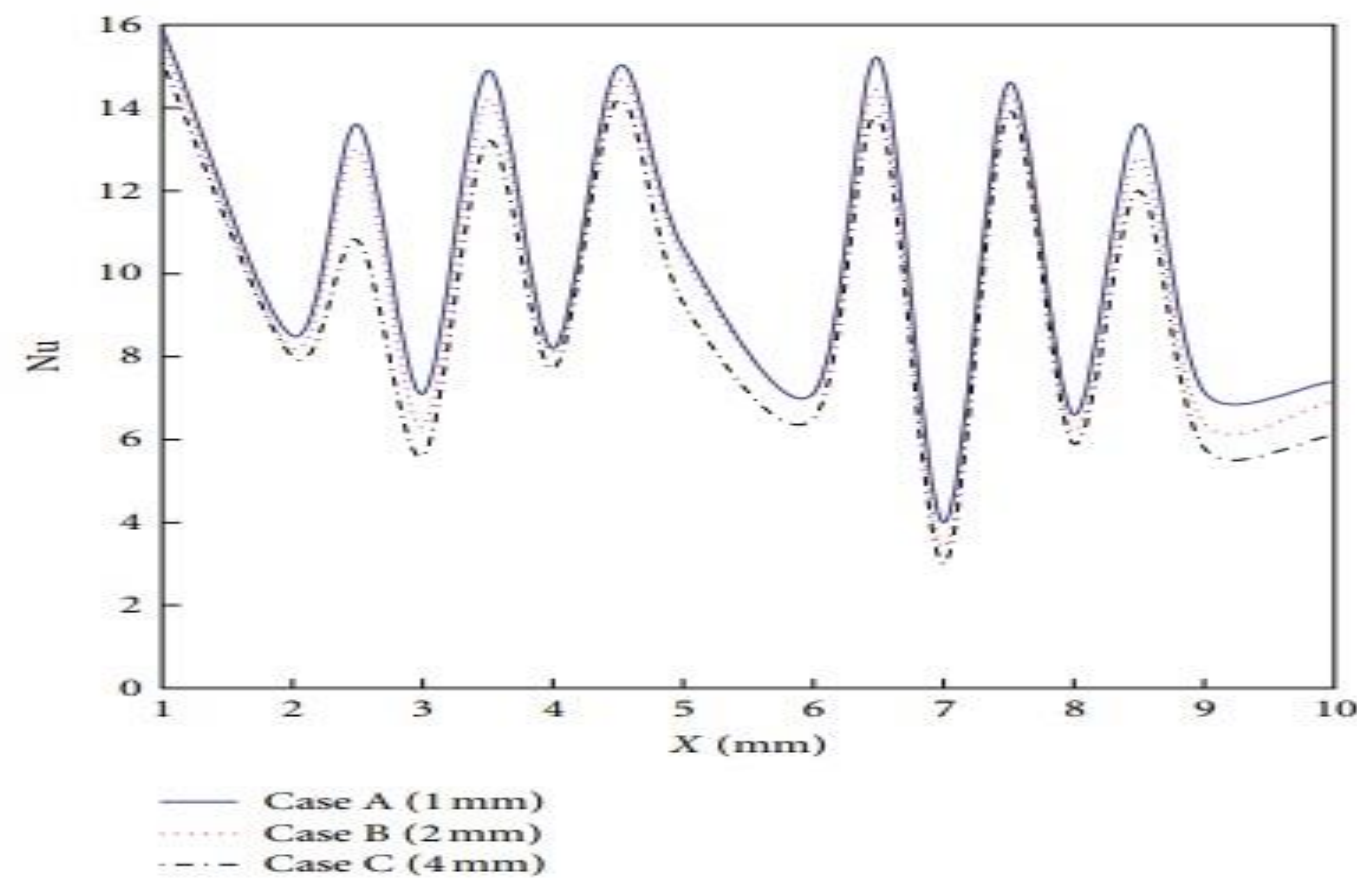

Figure 20: The deviation of $\mathrm{Nu}$ along the flow direction for variable fin pitch with uniform louver angle of $20 \circ$ and $\operatorname{Re}=500[30]$.

The averaged Nusselt number $(\mathrm{Nu})$ delivery with Reynolds number for altered fin pitch values (cases $\mathrm{A}-\mathrm{C}$ ) is shown in Figure 21. It may be understood that as the Reynolds number rises, Nu for all the cases inspected also rises closely linearly. This is as the Reynolds number is improved by growing the inlet velocity. As a consequence, there will be an increase in fluid velocity inside the flow over the fins. Therefore, this increase bothers the flow, and the heat transmission is reinforced when the Reynolds number is greater than before. From this figure, it is observed that the $\mathrm{Nu}$ for case $\mathrm{A}$ is the highest followed by cases $\mathrm{B}$ and $\mathrm{C}$ at all numbers of Reynolds number. The difference in $\mathrm{Nu}$ between the cases $\mathrm{A}-\mathrm{C}$ is more apparent at a higher Reynolds number. This is as, at developed Reynolds number, the border layers are thinner and the flow itself is almost allied with the louvers which cause the difference among cases A-C to be more substantial [30]. 


\subsection{Compact louvered heat exchanger}

This study has achieved an investigational study on automobile radiators to explore air-side heat transfer and pressure drop appearances of flow on louvered fins. Here have been performed tests for irregular and regular arrangements of louvers which have shown in Figures 22, 23 respectively. Thermal hydraulic performance of radiator has examined for various geometrical and flow parameters and experimental results compared with effectiveness NTU results. It has been found that heat transfer rate tends to increase with an increasing inlet air velocity but at the same velocity the symmetrical pattern has a higher heat transfer rate than asymmetrical. The reason is that the regular pattern has more louvers per tube and the more the number of louvers with small pitch are the extra common areas between the fluid flows. By increasing air velocity, the pressure drop in the airside will be increased but the symmetrical pattern louvered fin behaves better in pressure drop performance. In the same conditions of temperature and mass flow rates for inlet air and water, the cooling rate of outlet water and heating rate of an outlet air temperature of a regular pattern is greater than an irregular one. The overall conclusion obtained from the above work is that regular louver fin organization found best in thermal-hydraulic performance than irregular organization hence it is vital to study geometrical constraints and physical structure of heat exchanger in order to enhance performance.

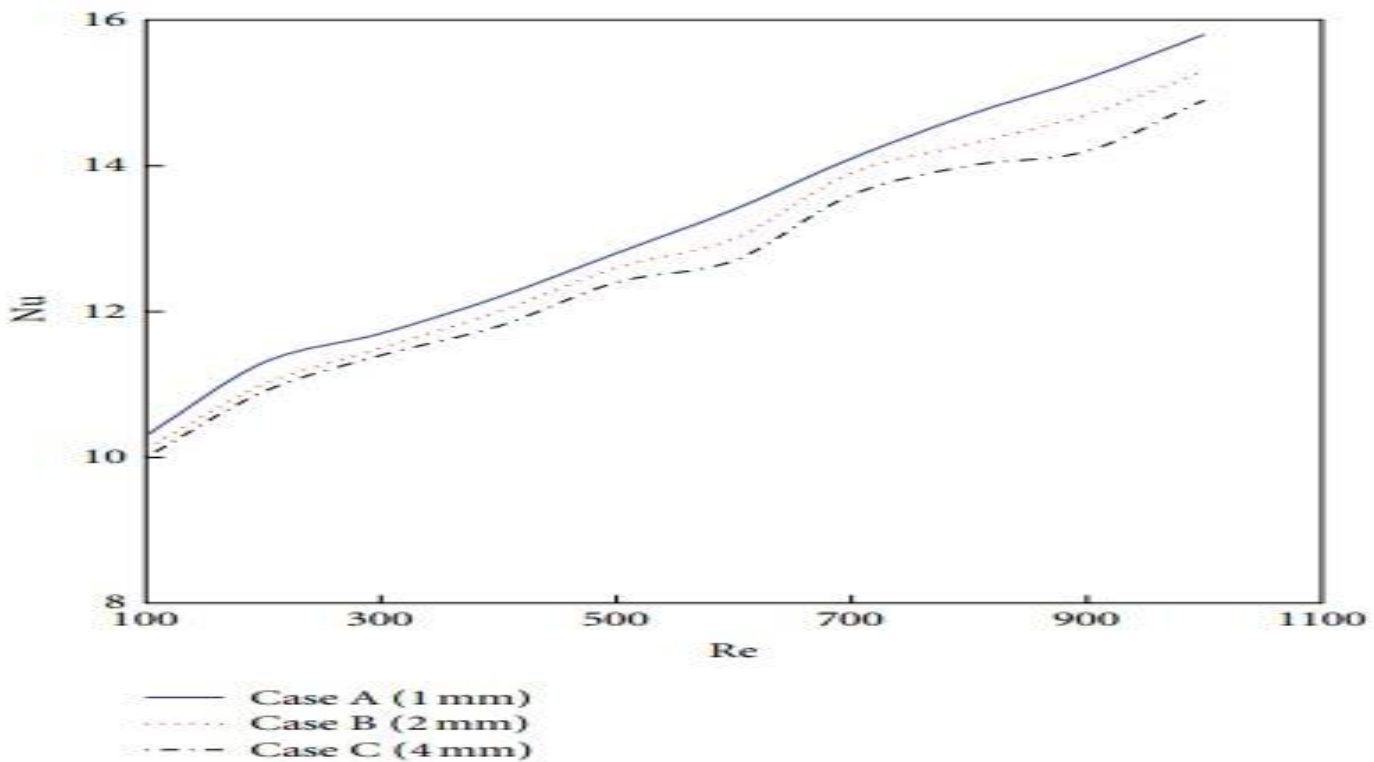

Figure 21: Variation of averaged, Nu versus Re for variable fin pitch with uniform louver angle of 20。 [30].
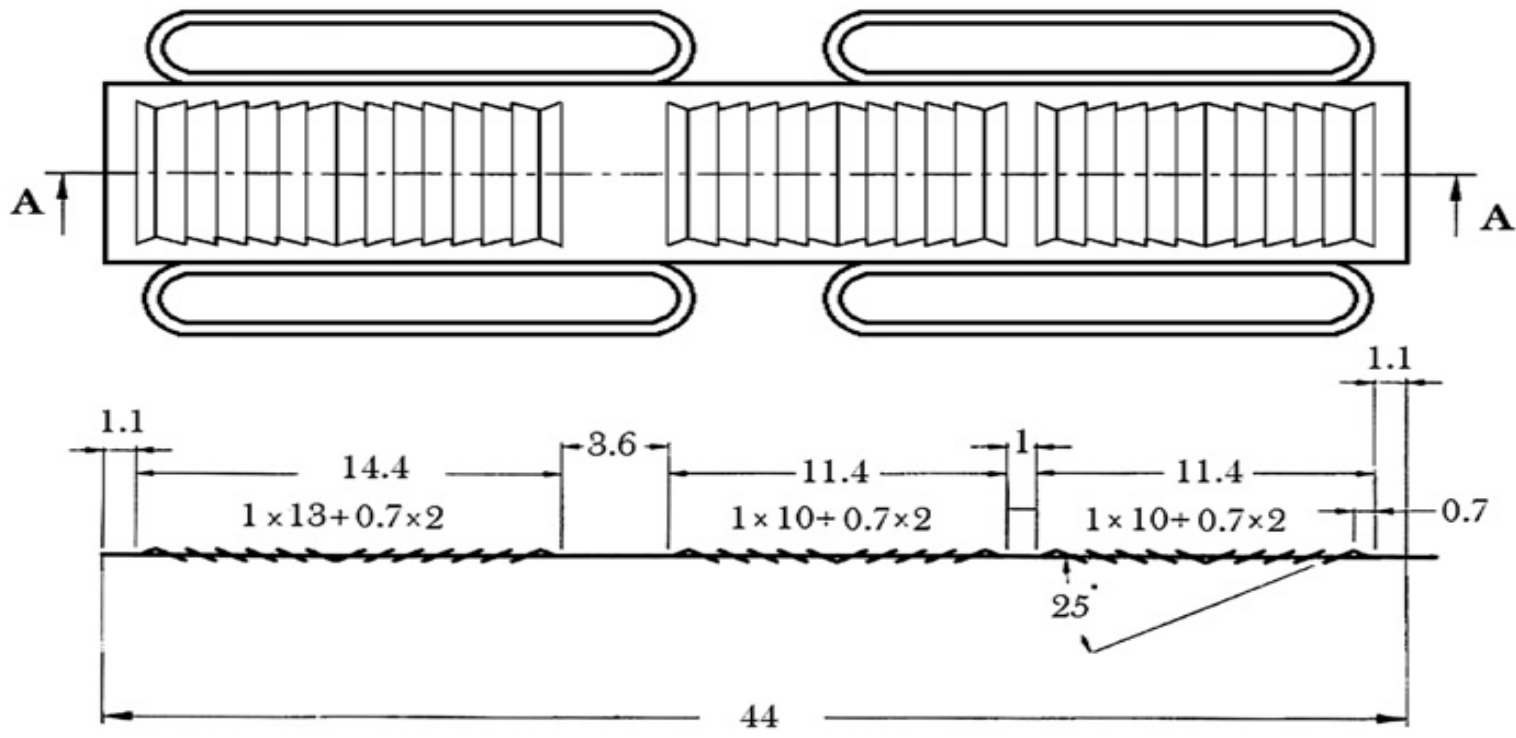

\section{Section A-A}

Scale 1:1

Figure 22: Asymmetrical arrangement of louvers [2]. 

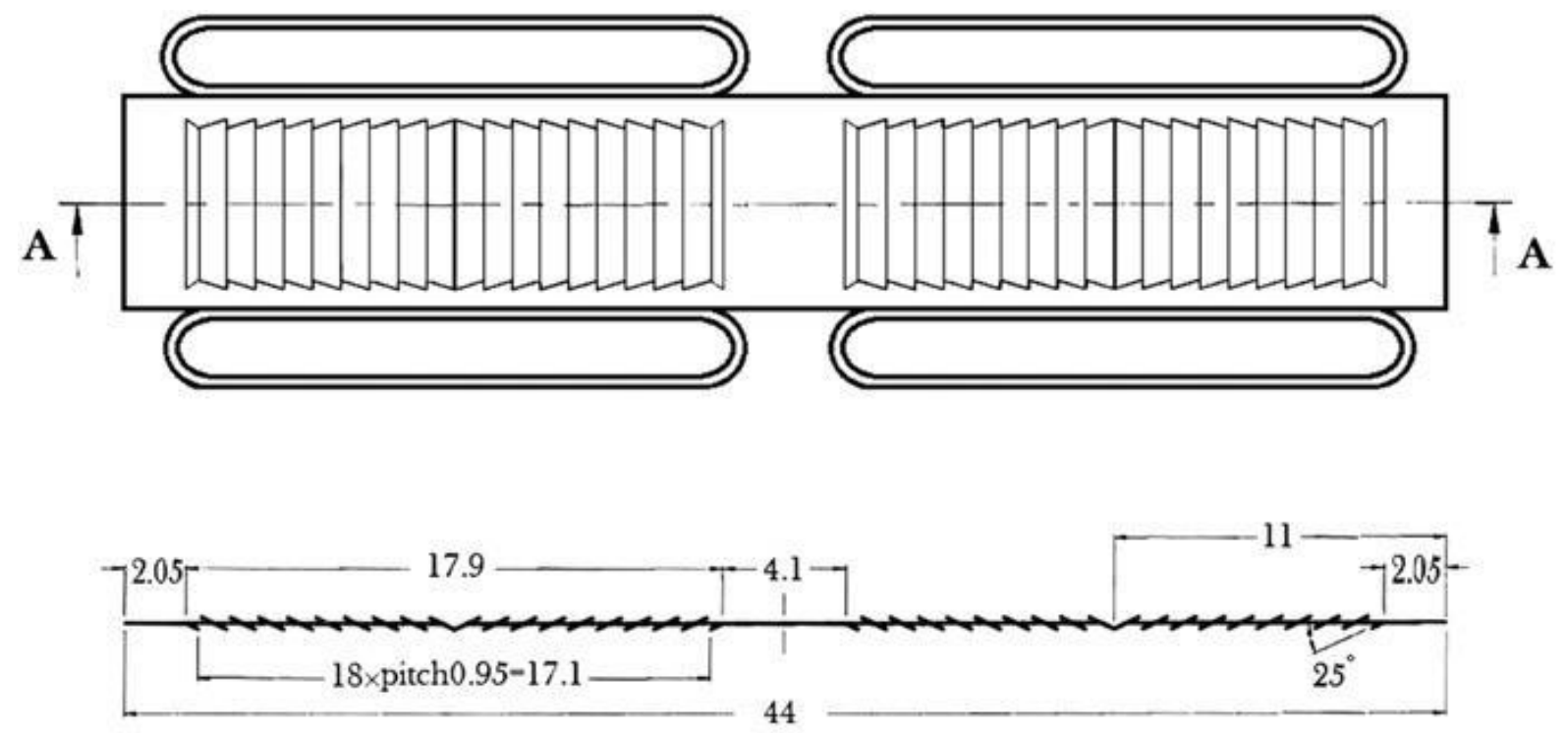

Section A-A

Scale 1:1

Figure 23: Symmetrical arrangement of louvers [2].

\section{SUMMARY}

It has shown from Figure 24 the greatest heat transfer enhancement is achieved approximately $118 \%$ for the louver fin heat exchangers with variable louver angle compared with general devices. The average value of heat transfer enhancement we studied about $58 \%$ for the multi-row fin and tube heat exchanger compared with regular devices. The minimum value of heat transfer enhancement is $9.3 \%$ for the compact louvered heat exchanger compared with general devices.

Table 4: Observation of recent investigations on various types of louver fin at different working conditions in term of heat transfer enhancement.

\begin{tabular}{|c|c|c|c|c|c|}
\hline $\begin{array}{l}\text { Louver } \\
\text { type }\end{array}$ & $\begin{array}{l}\text { Louver } \\
\text { arrangement }\end{array}$ & Ref. & $\begin{array}{l}\text { Working } \\
\text { fluid }\end{array}$ & Conditions & Observations \\
\hline \multirow{2}{*}{$\begin{array}{l}\text { Single } \\
\text { louvered } \\
\text { fins }\end{array}$} & $\begin{array}{l}\text { Single and } \\
\text { double row } \\
\text { tubes with } \\
\text { louvered fins }\end{array}$ & [4] & Air & $\begin{array}{l}\text { Reynolds } \\
\text { number from } \\
400 \text { to } 4000 \text {. } \\
\text { Temperature } \\
\text { s of the tube } \\
\text { surface and } \\
\text { inlet air } \\
\text { maintained } \\
\text { at } 358 \mathrm{~K} \text { and } \\
288 \mathrm{~K} \text {, } \\
\text { respectively }\end{array}$ & $\begin{array}{l}\text { (1) The local Nusselt number on the top surface } \\
\text { of each louver in the flow direction along the } \\
\text { length of fin for Reynolds number Red }=1000 \\
\text { is acquired. } \\
\text { (2) The heat transfer coefficient was increased } \\
\text { with the louver angle and reached a maximum } \\
\text { value at } 28-29^{\circ} \text { and then again decreased with } \\
\text { the increase in louver angle for fin pitch value } \\
\text { of } 2.17 \mathrm{~mm} \text {. } \\
\text { (3) The higher heat transfer coefficient value is } \\
\text { observed at a smaller louver pitch value of } 0.81 \\
\text { mm at optimal louver angle. }\end{array}$ \\
\hline & $\begin{array}{l}\text { Louvered fin } \\
\text { and tube } \\
\text { heat } \\
\text { exchanger }\end{array}$ & [5] & $\begin{array}{l}\text { Air with } \\
\text { constant } \\
\text { properti } \\
\text { es }\end{array}$ & $\begin{array}{l}\text { Variation of } \\
\text { Reynolds } \\
\text { number from } \\
1250 \text { to } 8100\end{array}$ & $\begin{array}{l}\text { (1) In this study established correlations can } \\
\text { describe } 100 \% \text { and } 86 \% \text { of totally } 186 \\
\text { numerical simulation data within } \pm 15 \% \\
\text { respectively in the extensive ranges of } \\
\text { constraints. } \\
\text { (2) The optimal louver angle was } 21^{\circ} \text { for } \\
\text { maximum increasing Colburn factor and } \\
\text { minimizing friction factor was gained by genetic } \\
\text { algorithm using the developed correlations. }\end{array}$ \\
\hline
\end{tabular}




\begin{tabular}{|c|c|c|c|c|c|}
\hline \multirow{3}{*}{$\begin{array}{l}\text { Multi } \\
\text { louvered } \\
\text { fins }\end{array}$} & $\begin{array}{l}\text { Multi row fin } \\
\text { and tube } \\
\text { heat } \\
\text { exchanger }\end{array}$ & [6] & Air & $\begin{array}{l}\text { The range of } \\
\mathrm{Re}_{\mathrm{H}} \text { numbers } \\
\text { within } \\
70-350 \text {. }\end{array}$ & $\begin{array}{l}\text { In this experiment, the increment in heat } \\
\text { transfer performance of } 58 \% \text { was acquired with } \\
\mathrm{Re}_{\mathrm{H}}=350 \text { when using louvered fin in place of } \\
\text { flat fins. }\end{array}$ \\
\hline & $\begin{array}{l}\text { Multi-region } \\
\text { louver fins } \\
\text { and flat tubes } \\
\text { heat } \\
\text { exchanger }\end{array}$ & [14] & Air & $\begin{array}{l}\text { Reynolds } \\
\text { numbers of } \\
400-1600\end{array}$ & $\begin{array}{l}\text { (1) The results show that the louver fin with } 4 \\
\text { regions and the louver fin with } 6 \text { regions are far } \\
\text { better than the conventional fin in overall } \\
\text { performance. } \\
\text { (2) At the same time, the louver fin with } 6 \\
\text { regions is also better than the louver fin with } 4 \text { - } \\
\text { region. }\end{array}$ \\
\hline & $\begin{array}{l}\text { Multi- } \\
\text { louvered fin } \\
\text { and flat } \\
\text { tube heat } \\
\text { exchanger }\end{array}$ & [16] & $\begin{array}{c}\text { Air and } \\
\text { water }\end{array}$ & $\begin{array}{l}\text { Reynolds } \\
\text { numbers of } \\
\text { 100-600. } \\
\text { velocity, of } \\
\text { 100-600 } \\
\text { water flow } \\
\text { rate } 0.32 \\
\mathrm{~m}^{3} / \mathrm{h} \text {. }\end{array}$ & $\begin{array}{l}\text { (1) In this part when used } 16 \mathrm{~mm} \text { flow depth } \\
\text { then the heat transfer coefficients do not change } \\
\text { much with louver angle. } \\
\text { (2) On the other side, for } 24 \mathrm{~mm} \text { flow depth, } \\
\text { the heat transfer coefficients rise with louver } \\
\text { angle and maximum at } 27^{\circ} \text { and again fall with } \\
\text { louver angle. } \\
\text { (3) And the friction factors rise with louver } \\
\text { angle, the j factor rises with louver angle, but its } \\
\text { effect on the j factor differs with flow depth. }\end{array}$ \\
\hline \multirow[b]{2}{*}{$\begin{array}{l}\text { Inclined } \\
\text { louvered } \\
\text { fins }\end{array}$} & $\begin{array}{l}\text { Inclined } \\
\text { louvered fin } \\
\text { heat } \\
\text { exchanger }\end{array}$ & [18] & Air & $\begin{array}{l}\text { Reynolds } \\
\text { numbers } \\
\text { varying from } \\
250 \text { to } 1300\end{array}$ & $\begin{array}{l}\text { (1) In this study, the fin pattern is observed to } \\
\text { have a greater friction factor (on average } 18 \% \text { ) } \\
\text { and convective heat transfer coefficient (on } \\
\text { average } 10 \% \text { ) for Reynolds numbers }>1000 \text {. } \\
\text { (2) For Reynolds numbers lower than } 1000 \text { the } \\
\text { convex louvered correlation slightly over } \\
\text { predicts the measured value, but the prediction } \\
\text { lies within the error margin. }\end{array}$ \\
\hline & $\begin{array}{l}\text { Variable } \\
\text { louver angle } \\
\text { heat } \\
\text { exchanger }\end{array}$ & [25] & Air & $\begin{array}{l}\text { Reynolds } \\
\text { number } \mathrm{Re}_{\mathrm{H}} \\
\text { (based on the } \\
\text { fin spacing } \\
\text { and the } \\
\text { frontal } \\
\text { velocity) } \\
\text { ranging from } \\
100 \text { to } 1100 .\end{array}$ & $\begin{array}{l}\text { (1) When Reynolds number is } 1075 \text {, the } \\
\text { temperature gradient is more prominent for a } \\
\text { higher louver angle that is the greater heat } \\
\text { transfer performance for large louver angle. } \\
\text { ( } 2) \text { In case A }(+2) \text {, case B }(+4) \text {, case C ( } 2 \text { ) and D } \\
(4) \text {, the supreme heat transfer development } \\
\text { inferred by } \mathrm{j} / \mathrm{j} 0 \text { are } 115 \%, 118 \%, 109 \% \text { and } \\
107 \% \text {, and the corresponding friction factor } \\
\text { ratio f/fO are } 116 \%, 119 \% 110 \% \text { and } 108 \% \text {, } \\
\text { correspondingly. } \\
\text { (3) And the area fall ratios are all enlarged for } \\
\text { five different cases of sequentially increased or } \\
\text { decreased louver angle compared to plain fin } \\
\text { surface and the extreme area reduction for case } \\
\text { B (+4) can reach up to } 25.5 \%\end{array}$ \\
\hline $\begin{array}{l}\text { vortex } \\
\text { generators }\end{array}$ & $\begin{array}{l}\text { Delta } \\
\text { winglet } \\
\text { vortex } \\
\text { generators }\end{array}$ & [27] & Air & $\begin{array}{l}\text { The } \\
\text { Reynolds } \\
\text { number } \\
\text { range 140- } \\
1220\end{array}$ & $\begin{array}{l}\text { (1) The maximum increase is } 16 \% \text { compared to } \\
\left.\text { the baseline geometry (at } \operatorname{Re}_{\mathrm{Dh}}=600\right) \text {. } \\
\text { (2) In this study delta winglets also create a } \\
\text { detriment in friction factor }\{\text { up to } 35 \% \text { at the } \\
\text { largest Reynolds number }\left(\operatorname{Re}_{\mathrm{Dh}}=1220\right) \text {. }\end{array}$ \\
\hline $\begin{array}{l}\text { compact } \\
\text { heat } \\
\text { exchanger }\end{array}$ & $\begin{array}{l}\text { Louvered fin } \\
\text { compact } \\
\text { heat } \\
\text { exchanger }\end{array}$ & [30] & Air & $\begin{array}{l}\text { Reynolds } \\
\text { number } \\
\text { ranged from } \\
100 \text { to } 1000 .\end{array}$ & $\begin{array}{l}\text { (1) Here the highest value of the Nusselt number } \\
\text { for case } B\left(+4^{\circ}\right) \text {. } \\
\text { (2) In here the Nusselt number and pressure } \\
\text { drop coefficient increase with decreasing with } \\
\text { fin pitch and increasing with Reynolds number. } \\
\text { Here enhancement of heat transfer for } \\
\text { minimum fin pitch ( } 1 \mathrm{~mm} \text { ) is more specious at } \\
\text { large Reynolds number. }\end{array}$ \\
\hline
\end{tabular}




\begin{tabular}{|l|l|l|l|l|}
\hline & & & $\begin{array}{l}\text { (1) Results showed that when used symmetrical } \\
\text { arrangement of louvered fins give a 9.3\% of } \\
\text { increment in heat transfer performance and an } \\
18.2 \% \text { minimization in pressure drop than the } \\
\text { irregular organization of louvered fin. }\end{array}$ \\
$\begin{array}{l}\text { Compact } \\
\text { louvered } \\
\text { heat } \\
\text { exchanger } \\
\text { pressure constant rate of heat transfer and } \\
\text { is perceived for the symmetrical arrangement of } \\
\text { fins. The outcomes from this study designate } \\
\text { that the arrangement of the louvered fins has } \\
\text { the main influence on the heat transfer and } \\
\text { pressure drop from that louver. }\end{array}$ \\
\hline
\end{tabular}

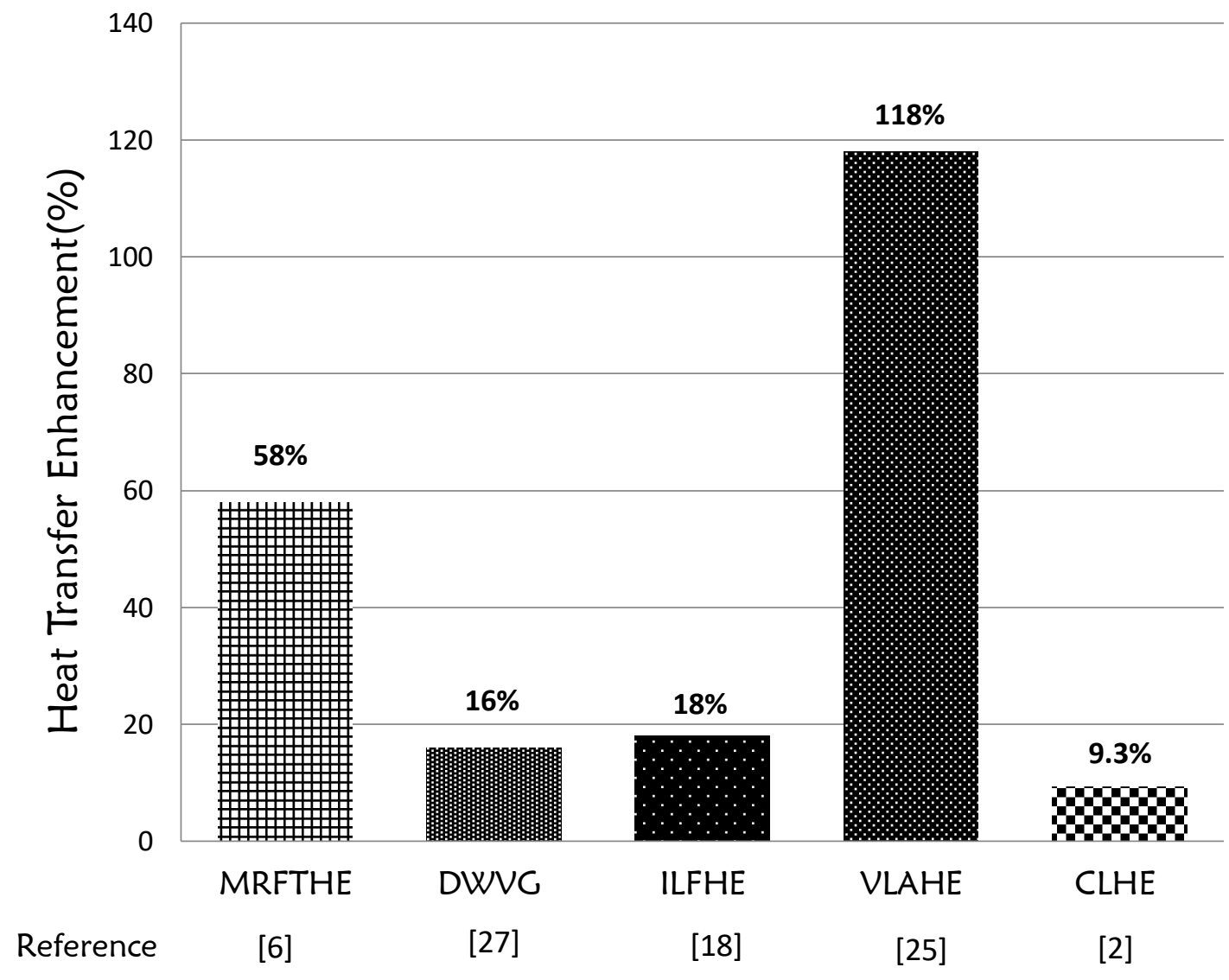

Figure 24: Graphical representation of comparison of heat transfer enhancement of various enhancement types.

\section{CONCLUSIONS}

Different kinds of louver patterns have been tested by researchers through its experimental and numerical studies. The heat transfer coefficient and pressure drop are two important characteristics used to optimize the thermalhydraulic performance of the louver fin heat exchanger. Optimum heat exchanger bears maximum heat transfer coefficient and minimum pressure drop characteristics. The effects of various geometrical parameters such as louver pitch, louver regions, louver angle, louver numbers, louver height, and flow parameters like air velocities are considered on the performance of louvered fin heat exchanger. The main findings of this present review can be described as follows:

1) When we studied multi louvered fin, in this segment for multi-row fin and tube heat exchanger, an increase in heat transfer enhancement is found $58 \%$ for $\mathrm{Re}_{\mathrm{H}}=350$.

2) In vortex generators for delta winglet vortex generators, the extreme enhancement of heat transfer increased to $16 \%$ compared to the baseline geometry (at $\operatorname{Re}_{\mathrm{Dh}}=600$ ). 
3) For inclined louvered fin heat exchanger, the studied fin pattern is found to have a greater enhancement on average $18 \%$ for Reynolds numbers lower than 1000.

4) For variable louver angle heat exchanger, the maximum heat transfer improvement achieved by $118 \%$ Reynolds number at 1075.

5) When we studied compact louvered head exchanger the results showed that symmetrical arrangements of louvered fins give a $9.3 \%$ heat transfer enhancement.

\section{REFERENCES}

[1] R.K. Shah, D.P. Sekulic (2003), Fundamentals of heat exchanger design, John Wiley \& Sons, 2003.

[2] A Vaisi, M Esmaeilpour and H. Taheria (2002). Experimental investigation of geometry effects on the performance of a compact louvered heat exchanger, Applied Thermal Engineering, 31, 2011, 3337- 3346. ManHoe Kim and Clark W Bullard (2002).

[3] A.A. Antoniou, M.R. Heikal, T.A. Cowell (1990), Measurements of local velocity and turbulence levels in arrays of louvered plate fins, in: Proceedings of the Ninth International Heat Transfer Conference, Jerusalem, 1990, pp. 105-110.

[4] V P Malapure, Sushanta K Mitra, A Bhattacharya (2007). Numerical investigation of fluid flow and heat transfer over louvered fins in compact heat exchanger, International Journal of Thermal Sciences, 46, 2007, $199-211$.

[5] Ali Sadeghianjahromia, SaeidKheradmanda, HossainNematib (2018). Developed correlations for heat transfer and flow friction characteristics of louvered finned tube heat exchangers, International Journal of Thermal Sciences, 129, 2018, 135-144.

[6] Čarija Z., Franković B., Perčić M., Čavrak M. (2014). Heat transfer analysis of fin-and-tube heat exchangers with flat and louvered fin geometries, International Journal of Refrigeration, 2014.

[7] C.J. Davenport (1980), Heat Transfer and Fluid Flow in Louvered Triangular Ducts, Ph.D. Thesis, Department of Mechanical Engineering, Lanchester Polytechnic, 1980.

[8] C.J. Davenport (1983), Correlation for heat transfer and friction characteristics of louvered fin, AICHE Symposium Series 79 (25), 19-27, 1983.

[9] A. Achaichia (1987), The performance of louvered tube-and-plate fin heat transfer surface, PhD thesis, Department of Mechanical and Production Engineering, Brighton Polytechnic, 1987.

[10] A. Achaichia, T.A. Cowell (1988), Heat transfer and pressure drop characteristics of flat and louvered plate fin surface, Experimental Thermal and Fluid Science 1,1988, 147-157.

[11] Z. Huihua, L. Xuesheung (1989), The experimental investigation of oblique angles and interrupted plate lengths for louvered fins in compact heat exchangers, Experimental Thermal and Fluid Science 2,1989, 100-106.

[12] H. Aoki, T. Shinagawa, K.K. Suga (1989), An experimental study of the local heat transfer characteristics in automotive louvered fins, Experimental Thermal and Fluid Science 2, 1989, 293-300.

[13] J.P. Rugh, J.T. Pearson, S. Ramadhyani (1992), A study of a very compact heat exchanger used for passenger compartment heating in automobiles, ASME Symposium Series HTD 201,1992, 15-24.

[14] Wei Li and Xialing Wang (2010). Heat transfer and pressure drop correlations for compact heat exchangers with multi-region louver fins, International Journal of Heat and Mass Transfer, 53, 2010, 2955-2962.

[15] DragiAntonijevic (2012). An engineering procedure for air side performance evaluation of flat tube heat exchangers with louvered fins, Heat Mass Transfer (2013), 49, 2012, 117-127.

[16] Air-side thermal hydraulic performance of multi louvered fin aluminum heat exchangers, International Journal of Refrigeration, 25, 2002, 390-400.

[17] T.P. Wenzel, J.G. Koomey, J.G. Rosenquist, M. Sanchez, J.W. Hanford (1997), Energy data sourcebook for the US residential sector, LBL-40297, Lawrence Berkeley National Laboratory, 1997.

[18] C. T Joen, H.-J. Steeman, A. Willockx, M. De Paepe (2006). Determination of heat transfer and friction characteristics of an adapted inclined louvered fin, Experimental Thermal and Fluid Science, 30, 2006, 319-327.

[19] R.L. Webb (1994), Principles of Enhanced Heat Transfer, John Wiley and Sons, New York, 1994.

[20] W.M. Kays, A.L. London (1950), Heat transfer and flow friction characteristics of some compact heat exchanger surfaces-Part I: Test system and procedure, Trans. ASME 72, 1950, 1075-1085.

[21] C.J. Davenport (1980), Heat transfer and fluid flow in louvred triangular ducts, Ph.D. thesis. CNAA, Lanchester Polytechnic Institute, England, 1980.

[22] C.J. Davenport (1983), Correlations for heat transfer and flow friction characteristics of louvred fin, AIChE Symposium series, 1983, pp. 19-27.

[23] R.L. Webb, P.A. Trauger (1991), Flow structure in the louvred fin heat exchanger geometry, Exp. Therm. Fluid Sci. 4 (1991) 205-217.

[24] J.Y. Jang, K.P. Shieh, H. Ay (2001), 3-D thermal-hydraulic analysis in convex louver finned -tube heat exchangers, ASHRAE Annual Meeting, Cincinnati, OH, USA, June 22-27, 2001, pp. 501-509.

[25] Ching-Tsun Hsieh and Jiin-Yuh Jang (2006). 3-D thermal- hydraulic analysis for louver fin heat exchangers with variable louver angle, Applied Thermal Engineering, 26, 2006, 1629-1639.

[26] European Union, The EU climate and energy package, Information collected from:<http://ec.europa.eu/clima/policies/package/index_en.htm>. 
[27] H. Huisseune (2011). Performance evaluation of louvered fin compact heat exchangers with vortex generators, Ph.D. thesis, Ghent University, Gent, Belgium, 2011.

[28] P. Gunnasegaran, N. H. Shuaib, M. F. AbdulJalal, and E. Sandhita (2012), "Numerical study of fluid dynamic and heat transfer in a compact heat exchanger using nanofluids," ISRN Mechanical Engineering, vol. 2012, Article ID 585496, 11 pages, 2012.

[29] K. Y. Leong, R. Saidur, S. N. Kazi, and A. H. Mamun (2010), "Performance investigation of an automotive car radiator operated with nanofluid-based coolants (nanofluid as a coolant in a radiator)," Applied Thermal Engineering, vol. 30, no. 17-18, pp. 2685-2692, 2010

[30] P. Gunnasegaran, N. H. Shuaib and M. F. Abdul Jalal (2012). The Effect of Geometrical Parameters on Heat Transfer Characteristics of Compact Heat Exchanger with Louvered Fins, International Scholarly Research Network ISRN Thermodynamics, Volume 2012, Article ID 832708, 10 pages. 